\title{
Toxic Effect of Acute Cadmium and Lead Exposure in Rat Blood, Liver, and Kidney
}

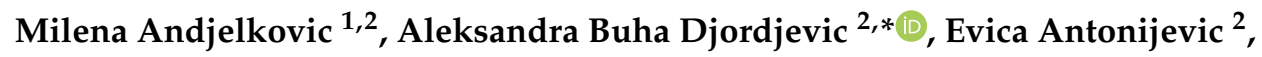 \\ Biljana Antonijevic ${ }^{2}$, Momcilo Stanic ${ }^{1}$, Jelena Kotur-Stevuljevic ${ }^{3}{ }^{\circledR 0}$, \\ Vesna Spasojevic-Kalimanovska ${ }^{3}$, Milos Jovanovic ${ }^{4}$, Novica Boricic ${ }^{5}$, \\ David Wallace $^{6}\left(\right.$ iD and Zorica Bulat ${ }^{2}$ (D) \\ 1 Health center Kosovska Mitrovica, 38220 Kosovska Mitrovica, Serbia; \\ millena.andjelkovic@gmail.com (M.A.); momcilostanickm@gmail.com (M.S.) \\ 2 Department of Toxicology "Akademik Danilo Soldatović”, Faculty of Pharmacy, University of Belgrade, \\ 11221 Belgrade, Serbia; evicaa@pharmacy.bg.ac.rs (E.A.); abiljana@pharmacy.bg.ac.rs (B.A.); \\ zorica.bulat@pharmacy.bg.ac.rs (Z.B.) \\ 3 Department of Medical Biochemistry, Faculty of Pharmacy, University of Belgrade, 11221 Belgrade, Serbia; \\ jkotur@pharmacy.bg.ac.rs (J.K.-S.); vkalima@pharmacy.bg.ac.rs (V.S.-K.) \\ 4 Institute of Physiology and Biochemistry, Faculty of Biology, University of Belgrade, 11221 Belgrade, Serbia; \\ jovanovic@bio.bg.ac.rs \\ 5 Institute of Pathology, Faculty of Medicine, University of Belgrade, 11221 Belgrade, Serbia; \\ novica.boricic@med.bg.ac.rs \\ 6 Department of Pharmacology and Toxicology, School of Biomedical Science, Oklahoma State University \\ Center for Health Sciences, Tulsa, OK 741071898, USA; david.wallace@okstate.edu \\ * Correspondence: aleksandra@pharmacy.bg.ac.rs; Tel.: +381-11-3951-248
}

Received: 15 December 2018; Accepted: 16 January 2019; Published: 18 January 2019

\begin{abstract}
Background: Cadmium and lead are widespread and non-biodegradable pollutants of great concern to human health. In real life scenarios, we are exposed to mixtures of chemicals rather than single chemicals, and it is therefore of paramount importance to assess their toxicity. In this study, we investigated the toxicity of $\mathrm{Cd}$ and $\mathrm{Pb}$ alone and as a mixture in an animal model of acute exposure. Methods: Experimental groups received a single treatment of aqueous solution of Cd-chloride (15 and $30 \mathrm{mg} / \mathrm{kg}$ body weight (b.w.) and Pb-acetate $(150 \mathrm{mg} / \mathrm{kg}$ b.w.), while the mixture group received $15 \mathrm{mg} \mathrm{Cd} / \mathrm{kg}$ b.w. and $150 \mathrm{mg} \mathrm{Pb} / \mathrm{kg}$ b.w. Toxic effects of individual metals and their mixture were investigated on hematological and biochemical parameters, and the redox status in the plasma, liver, and kidneys of treated Wistar rats. Results: Tissue-specific changes were recorded in various parameters of oxidative damage, while the accumulation of metals in tissues accompanied the disturbances of both hematological and biochemical parameters. It was observed that the level of toxic metals in tissues had a different distribution pattern after mixture and single exposure. Conclusions: Comprehensive observations suggest that exposure to $\mathrm{Cd}$ and $\mathrm{Pb}$ mixtures produces more pronounced effects compared to the response observed after exposure to single metal solutions. However, further research is needed to confirm toxicokinetic or toxicodynamic interactions between these two toxic metals in the organisms.
\end{abstract}

Keywords: cadmium; lead; mixture; oxidative stress; toxicity; rats

\section{Introduction}

Cadmium $(\mathrm{Cd})$ and lead $(\mathrm{Pb})$ are ubiquitous and non-biodegradable pollutants representing a great concern to human health. Both metals are naturally distributed, but industrial development has dramatically increased their concentrations in the environment [1-3]. Industries associated with 
smelting and mining, manufacturing of batteries, pigments, and ceramic are well-known emitters of $\mathrm{Cd}$ and $\mathrm{Pb}$. Increased emissions of both metals in the environment and their non-biodegradability have increased the risk of human exposure. The main routes of $\mathrm{Cd}$ and $\mathrm{Pb}$ exposure are ingestion and inhalation due to their presence in food, air, and tobacco leaves [1-4]. The World Health Organization (WHO) has published a list of 10 chemicals or groups of chemicals of concern for human health, which includes $\mathrm{Cd}$ and $\mathrm{Pb}$ [5]. Additionally, the US Agency for Toxic Substances and Disease Registry (ATSDR) ranked $\mathrm{Cd}$ in seventh and $\mathrm{Pb}$ in second place on the priority list of dangerous substances [6].

Many in vivo and in vitro studies have been conducted to determine the exact mechanisms of toxicity of $\mathrm{Cd}$ and $\mathrm{Pb}$. The present body of knowledge suggests oxidative stress as one of the critical mechanisms of toxicity of both metals, even though neither of these metals is a Fenton's metal [7-10]. Other possible mechanisms of toxicity are binding to oxygen, nitrogen, and sulphur ligands, which may affect numerous enzymes and proteins [7,11]; interaction with bioelements [12-14]; inhibition of apoptosis [15]; and changes in DNA structure and the inhibition of damaged DNA repair, which may lead to aberrant gene expression [16-18].

After absorption, $\mathrm{Cd}$ and $\mathrm{Pb}$ are distributed in the organisms via red blood cells or proteins $[19,20]$. A major amount of $\mathrm{Cd}$ in red blood cells is bound to high-molecular-weight proteins, while a minor amount is bound to hemoglobin [19]. However, when Pb enters the cell, most of it is bound to hemoglobin rather than the membrane of red blood cells [21]. The hematopoietic system is one of the most sensitive systems and blood represents not only the mode of transportation, but also the critical toxicity target of $\mathrm{Cd}$ and $\mathrm{Pb}[21,22]$. Both metals may lead to anemia by various mechanisms $[2,10,23]$. Cadmium and $\mathrm{Pb}$ are transported to the liver, in which they can cause damage and disturbed function. Liver damage can be confirmed by histopathological findings and is often accompanied by increased blood enzyme levels and reduced protein synthesis [24-28]. Toxic effects on kidneys are represented through the structure damage of kidneys and changes in the excretory function $[24,25,28,29]$. In addition to the metal-toxicity observed in the hematopoietic system, liver, and kidneys, metals have been implicated in various other organ toxicity. Cadmium has been shown to exert toxicity in pancreas, endocrine, cardiovascular, immune, and reproductive systems [1,3,30-32], while $\mathrm{Pb}$ toxicity has been linked to toxic effects on the nervous, cardiovascular, and reproductive systems $[2,10,21,33]$. The majority of the $\mathrm{Pb}$ body burden is in mineralizing tissues (bones and teeth) [34]. The fact that $\mathrm{Cd}$ and $\mathrm{Pb}$ have a comparable radius to $\mathrm{Ca}$ ions means that both toxic metals can lead to bone damage by displacing Ca ions [11,35]. The International Agency for Research on Cancer (IARC) has classified $\mathrm{Cd}$ as carcinogenic to humans (Group 1), while inorganic $\mathrm{Pb}$ has been classified as probably carcinogenic to humans (Group 2A) based on limited evidence in humans and sufficient evidence in animals $[21,22,36]$.

Humans are exposed to mixtures of chemicals rather than an individual chemical, and therefore, it is important to establish whether chemical mixtures produce a more pronounced effect compared to individual chemicals. The importance of the evaluation of "cocktail effects" has been summarized in the European Commission statement, which highlighted that even low-level exposure to a complex cocktail of pollutants over decades could have a significant effect on the health status of European citizens [37]. The co-exposure to $\mathrm{Cd}$ and $\mathrm{Pb}$ may implicate possible synergism or antagonism, additive, or new effects that are not observed for single metal exposure [7,38]. A sub-chronic oral toxicity study with different $\mathrm{Cd}$ and $\mathrm{Pb}$ doses showed that the main target organs were the blood, liver, and kidneys [24]. Fifteen days following the intraperitoneal administration (i.p.) of a $\mathrm{Cd}$ and $\mathrm{Pb}$ mixture, Pillai et al. [39] reported that $\mathrm{Cd}$ was the more reactive of the two metals, while Masso et al. [40] suggested a possible antagonistic effect between $\mathrm{Cd}$ and $\mathrm{Pb}$. Clearly, the interactions between the two metals in a combined mixture are complex and warrant further investigation.

We decided to investigate the toxicity of a $\mathrm{Cd}$ and $\mathrm{Pb}$ mixture in an animal model of acute exposure. The effects of the exposure to single metals and their mixture were investigated on hematological and biochemical parameters and redox status in the plasma, liver, and kidneys of 
treated rats. Furthermore, the distribution of metals and bioelements was investigated in selected tissues, as well as their histopathology.

\section{Materials and Methods}

\subsection{Chemicals}

All reagents and chemicals were of analytical grade quality or higher purity. Cadmium chloride $\left(\mathrm{CdCl}_{2} \times \mathrm{H}_{2} \mathrm{O}\right.$, Merck, Germany) and lead acetate $\left(\mathrm{Pb}\left(\mathrm{CH}_{3} \mathrm{COO}\right)_{2} \times 3 \mathrm{H}_{2} \mathrm{O}\right.$, Centrohem, Serbia) were used for oral administration solutions. Standard solutions of $\mathrm{Cd}, \mathrm{Pb}$, copper $(\mathrm{Cu})$, and zinc $(\mathrm{Zn})$ (Merck, Germany) were used to create calibration curves for toxic metals and bioelements analysis, while $\mathrm{CHNO}_{3}$ (65\%, Merck, Germany) and $\mathrm{H}_{2} \mathrm{O}_{2}$ (30\%, Sigma-Aldrich, Germany) were used for tissue mineralization. All chemical and reagents for the examination of antioxidant status were purchased from Sigma-Aldrich Chemie (Germany).

\subsection{Animals}

Male Wistar rats were purchased from the Military Medical Academy (Belgrade, Serbia). The experiment was performed on male albino Wistar rats weighing approximately $250 \mathrm{~g}$. Animals were housed under standard controlled conditions (temperature $25 \pm 3{ }^{\circ} \mathrm{C}$, relative humidity of $35 \%$ to $60 \%, 12$-h light-dark cycle) and allowed free access to standard rat chow and drinking water during the experiment. All experimental procedures were approved by the Ethical Committee on Animal Experimentation of the University of Belgrade, Faculty of Pharmacy (Serbia, project code number III 46009).

\subsection{Study Design and Experimental Procedure}

Following two weeks of acclimatization, rats were randomly divided into five groups: one control group and four experimental groups. Experimental groups that received a single dose of $\mathrm{Cd}$ and $\mathrm{Pb}$ were composed of six animals, while the number of rats in the $\mathrm{Cd}$ and $\mathrm{Pb}$ mixture group was seven. The control group was composed of eight animals. Experimental groups received a single treatment of aqueous solution of $\mathrm{CdCl}_{2}$ and $/$ or $\mathrm{Pb}\left(\mathrm{CH}_{3} \mathrm{COOH}\right)_{2}$ in doses: $15 \mathrm{mg} \mathrm{Cd} / \mathrm{kg}$ body weight (b.w.) ( $\mathrm{Cd}_{15}$ group), $30 \mathrm{mg} \mathrm{Cd} / \mathrm{kg}$ b.w. ( $\mathrm{Cd}_{30}$ group), $150 \mathrm{mg} \mathrm{Pb} / \mathrm{kg}$ b.w. ( $\mathrm{Pb}_{150}$ group), and $15 \mathrm{mg}$ $\mathrm{Cd} / \mathrm{kg}$ b.w. and $150 \mathrm{mg} \mathrm{Pb} / \mathrm{kg}$ b.w. $\left(\mathrm{Cd}_{15}+\mathrm{Pb}_{150}\right.$ group). The control group was treated with water only. The selection of experimental doses was based on our previous research, as well as literature data $[24,41,42]$. Also, a lower dose of $\mathrm{Cd}$ was selected for the mixture treatment in accordance with the results of our previous research [42]. The treatment of all animals was performed by an oral gavage in a volume of $1 \mathrm{~mL} / \mathrm{kg}$ b.w. Animals were sacrificed $24 \mathrm{~h}$ after treatment under light anesthesia.

\subsection{Tissue Preparations}

Blood samples were collected by cardiac puncture through the diaphragm, after anesthetic administration. One aliquot of blood with anticoagulant (heparin) was used for the measurement of hematological parameters, and a second aliquot was wet digested for toxic metals and bioelements measurement. The remaining amount of blood with anticoagulant (heparin) was used to obtain plasma, while the rest of the blood was collected in test tubes without anticoagulant for obtaining serum. Plasma and serum were separated and frozen $\left(-80^{\circ} \mathrm{C}\right.$ for plasma and $-20^{\circ} \mathrm{C}$ for serum) for redox status and biochemical assays, respectively. Organ systems examined, the liver and kidneys, were removed and separated into three parts. One tissue sample was immediately frozen in liquid nitrogen and stored at $-80^{\circ} \mathrm{C}$ for the investigation of antioxidant status, a second was stored at $-20^{\circ} \mathrm{C}$ for toxic metals and bioelements analysis, and a third tissue sample was preserved in formalin for histopathological examination. 


\subsection{Toxic Metals and Bioelements Analysis}

Heparin blood (approximately $1 \mathrm{~mL}$ ) and wet tissue samples weighing about $500 \mathrm{mg}$ were placed in Teflon containers with $7 \mathrm{~mL} \mathrm{cHNO}_{3}$ and $1 \mathrm{~mL} \mathrm{H}_{2} \mathrm{O}_{2}$ and mineralized (Milestone START D, SK-10T, Milestone Srl, Sorisole, Italy). Digestion was carried out according to the Milestone's recommendations. The amount of $\mathrm{Cd}, \mathrm{Pb}, \mathrm{Cu}$, and $\mathrm{Zn}$ in the blood and tissue samples was determined by atomic absorption spectrophotometry (AAS GTA 120 graphite tube atomizer, 200 series AA, Agilent Technologies, Santa Clara, CA, USA). Matrix modifier, 10\% Triton $\mathrm{X}$, and $0.5 \% \mathrm{NH}_{4} \mathrm{H}_{2} \mathrm{PO}_{4}$ have been used throughout the whole experimental assay. The accuracy of AAS analyses was validated with standard reference material (SRM) whole blood Level 2 (Seronorm ${ }^{\mathrm{TM}}$, Sero, Billingstad, Norway) for blood analyses and with SRM 1577c - Bovine liver (LGS Standard, UK) for tissue samples.

\subsection{Hematology Analysis}

Hematological parameters were measured by the CELL-DYN Ruby analyzer (Abbott, Abbott Park, IL, USA). Multi-angle polarized scatters separation was used for white blood cell and dual angle optical analysis for platelets count. The following hematological parameters were examined: white blood cell count (WBC) with WBC differential count (neutrophils, eosinophils, lymphocytes, basophils, and monocytes), red blood cell count (RBC), hemoglobin concentration (HGB), hematocrit (HCT), mean corpuscular volume (MCV), mean corpuscular hemoglobin $(\mathrm{MCH})$, mean corpuscular hemoglobin concentration (MCHC), and platelet count (PLT).

\subsection{Biochemical Assays}

The measured biochemical parameters in rat serum included blood urea nitrogen (BUN), creatinine (CRE), uric acid (UA), total serum proteins (TP), albumin (ALB), direct bilirubin (DB), total bilirubin (TB), aspartate aminotransferase (AST), alanine aminotransferase (ALT), alkaline phosphatase (ALP), amylase (AMY), lactate dehydrogenase (LDH), iron (Fe), calcium (Ca), inorganic phosphorus $(\mathrm{P})$, magnesium $(\mathrm{Mg})$, and chloride $(\mathrm{Cl})$. All biochemical assays were performed with commercial reagents and according to good laboratory practices on the Beckman Coulter analyzer (AU 480, Beckman Coulter, Brea, CA, USA). Calibrators of tests were traceable to the National Institute of Standards and Technology (NIST) SRM and Beckman Coulter Master Calibrators.

\subsection{Redox Status Analysis}

Tissues samples (liver and kidneys) for redox status assessment were rapidly excised, washed in ice-cold $0.9 \% \mathrm{NaCl}$, and homogenized in nine volumes of buffer $(0.1 \mathrm{~mol} / \mathrm{L}$ phosphate buffer, pH 7.4) [43]. Homogenization was carried out by the T10 basic Ultra-Turrax homogenizer (IKA, Staufen, Germany). A portion of homogenate was used for the determination of malondialdehyde (MDA), while the rest was centrifuged for $10 \mathrm{~min}\left(\right.$ at $4{ }^{\circ} \mathrm{C}$ ) at $800 \mathrm{~g}$ and then for $20 \mathrm{~min}$ at $9500 \mathrm{~g}$ to get post-mitochondrial supernatant (PMS). Assessment of the following parameters was performed: MDA, advanced oxidation protein products level (AOPP), total thiol (SH) groups level, prooxidative-antioxidative balance ( $\mathrm{PAB})$, total antioxidative status (TAS), total oxidative status (TOS), oxidative stress index (OSI), and superoxide dismutase activity (SOD) at ILAB 300 plus analyzer (Instrumentation Laboratory, Milan, Italy) and Cary 60 UV-VIS spectrophotometer (Agilent Technologies, Santa Clara, CA, USA).

The concentration of MDA was determined as a thiobarbituric acid-reactive substance (TBARS) by a spectrophotometric assay based on the absorption maximum of the malondialdehyde complex and other TBARS with thiobarbituric acid at $535 \mathrm{~nm}$ [44]. The principle of the method for determining AOPP is a two-step measurement of sample absorption in the wavelength range of $200-400 \mathrm{~nm}$, with a characteristic peak at $340 \mathrm{~nm}$. The obtained difference in the measured absorbance values of $340 \mathrm{~nm}$ indicates the AOPP value for the given sample [45]. The principle of the method for determining the total SH-groups is as follows: aliphatic thiol compounds in the base environment are reacted 
with DTNB (2,2'-dinitro-5,5'-dithio-benzoic acid), wherein one mol of thiol produces one mol of $p$-nitrophenol. The resulting color has an absorption peak at $412 \mathrm{~nm}$ [46]. Alamandari et al. [47] have developed a method for the determination of PAB using 3,3',5,5'-tetramethylbenzidine as a chromogen. The method principle for TAS assessment is as follows: the colorless reduced form of ABTS is oxidized to dark green color $\mathrm{ABTS}^{+}$with hydrogen peroxide in an acidic medium (acetate buffer $30 \mathrm{mM}$, $\mathrm{pH}$ 3.6) [48]. The TOS method is based on oxidants present in the sample to oxidize the ferrous ion from the $o$-dianisidine complex to ferric ion. The build-up intensity is directly proportional to the concentration of oxidants present in the sample, with an absorption peak at $560 \mathrm{~nm}$ [49]. Oxidative stress degree was calculated as the ratio between TOS and TAS [50]. The method of determining the activity of superoxide dismutase enzymes (SOD, EC 1.15.1.1.) was established in 1971 by Misra and Fridovich [51]. The method is based on the ability of SOD to inhibit the spontaneous autoxidation of adrenaline at $\mathrm{pH}$ 10.2. Protein levels in tissues were determined by the Bradford method [52] using bovine albumin as the standard, while plasma protein levels were determined by the standard biuret method [53].

\subsection{Histopathological Analysis}

The preserved tissues (liver and kidneys) were subjected to histopathological examination. Microscopic examinations on paraffin embedded $5 \mu \mathrm{m}$ tissue sections with hematoxylin-eosin were performed. Each section was examined under an optical microscope.

\subsection{Statistical Analysis}

Statistical analysis was performed using SPSS 18.0 (SPSS Inc. Chicago, IL, USA) software. One-way ANOVA and Kruskal-Wallis nonparametric tests were used. These statistical tests were followed by LSD or the Mann-Whitney $U$ test, respectively. $p$-Values less than 0.05 were considered significant.

\section{Results}

\subsection{Cadmium and Lead Concentration in Tissues}

Experimental groups treated with a single dose of $\mathrm{Cd}$ had a statistically higher blood concentration of $\mathrm{Cd}$ compared to values in the control group. Blood concentrations of $\mathrm{Cd}$ in the $\mathrm{Cd}-\mathrm{Pb}$ mixture group were not different from control values. Both experimental groups receiving a single dose of $\mathrm{Cd}$ (15 or $30 \mathrm{mg} / \mathrm{kg}$ ) demonstrated significantly higher levels of $\mathrm{Cd}$ in the liver compared to the control group $(p<0.001)$, while the $\mathrm{Cd}_{30}$ group had a higher concentration of $\mathrm{Cd}$ in the liver compared to the $\mathrm{Cd}_{15}$ group $(p<0.01)$. The measured level of liver $\mathrm{Cd}$ in the experimental group receiving $\mathrm{Cd}$ and $\mathrm{Pb}$ mixture exhibited a statistically significant difference when compared to the control, while difference from the $\mathrm{Cd}_{15}$ group was not observed. Additionally, both $\mathrm{Cd}$ groups $\left(\mathrm{Cd}_{15}\right.$ group and $\mathrm{Cd}_{30}$ group) showed statistically significant higher levels of $\mathrm{Cd}$ in kidneys compared to the control group $(p<0.001)$. Experimental groups treated with $30 \mathrm{mg} \mathrm{Cd} / \mathrm{kg}$ b.w. had a higher concentration of $\mathrm{Cd}$ in the kidneys compared to $15 \mathrm{mg} \mathrm{Cd} / \mathrm{kg}$ b.w. $(p<0.05)$. After mixture treatment, the $\mathrm{Cd}$ concentration in the kidneys showed a statistically significant difference when compared to the control and $\mathrm{Cd}_{15}$ group $(p<0.001$, $p<0.01$, respectively).

Experimental groups that received $\mathrm{Pb}$ had higher concentrations of lead in all three of the investigated mediums: blood, liver, and kidneys, compared to values in the control group. Additionally, the $\mathrm{Cd}_{15}+\mathrm{Pb}_{150}$ group had a statistically higher $\mathrm{Pb}$ concentration in the liver and kidneys compared to the $\mathrm{Pb}_{150}$ group $(p<0.01, p<0.05$ respectively), while the difference was not observed in blood. Levels of $\mathrm{Cd}$ and $\mathrm{Pb}$ in investigated tissues are shown in Figures 1 and 2. 


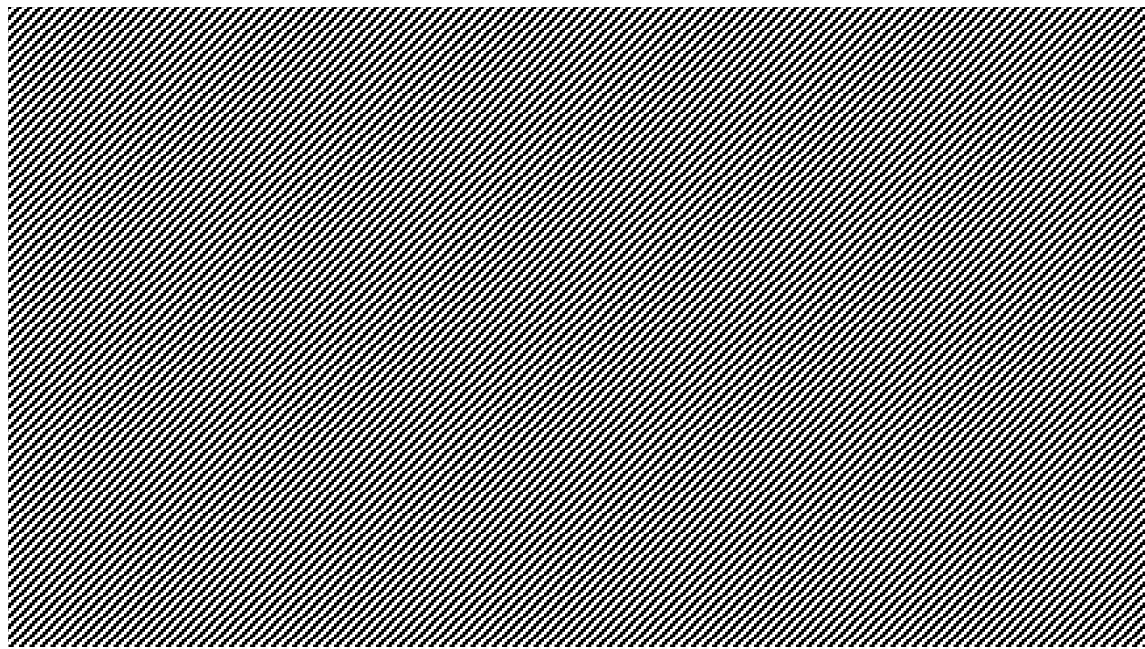

Figure 1. Cadmium concentration in rat blood, liver, and kidneys after acute exposure to $\mathrm{Cd}$ and $\mathrm{Pb}$. Cadmium levels in blood are expressed as $\mu \mathrm{g} \mathrm{Cd} / \mathrm{L}$ and as $\mu \mathrm{g} \mathrm{Cd} / \mathrm{kg}$ (wet tissues) in liver and kidneys. Values are presented as means and S.D. Statistically significant differences $(p<0.05)$ compared to control group are indicated by ${ }^{*}{ }^{\dagger} \mathrm{Cd}_{15}$ group. Statistical evaluation was performed using one-way ANOVA followed by LSD post-hoc test for pairwise comparison. ${ }^{*+} p<0.05 ;{ }^{* *}{ }^{+\dagger} p<0.01 ;{ }^{* * *}{ }^{++\dagger} p<0.001$.

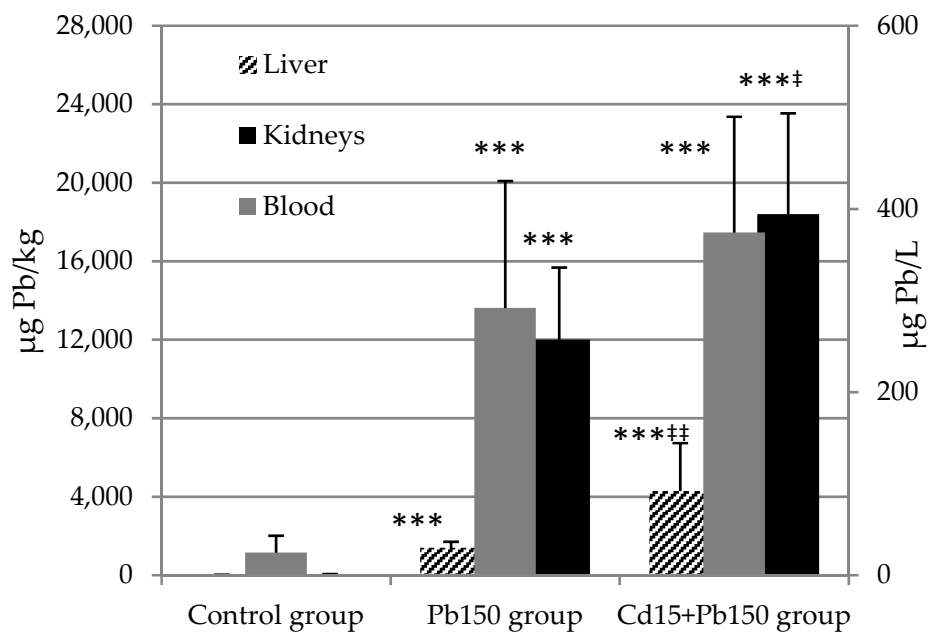

Figure 2. Lead concentration in rat blood, liver, and kidneys after acute exposure to $\mathrm{Cd}$ and $\mathrm{Pb}$. Lead levels in blood are expressed as $\mu \mathrm{g} \mathrm{Pb} / \mathrm{L}$ and as $\mu \mathrm{g} \mathrm{Pb} / \mathrm{kg}$ (wet tissues) in liver and kidneys. Values are presented as means and S.D. Statistically significant differences $(p<0.05)$ compared to control group are indicated by ${ }^{*}, \ddagger \mathrm{Pb}_{150}$ group. Statistical evaluation was performed using one-way ANOVA followed by LSD post-hoc test for pairwise comparison. ${ }^{*} \neq p<0.05 ;{ }^{* *}$ 㧊 $p<0.01$; ${ }^{* * *}$ 㧊 $p<0.001$.

\subsection{Hematology}

Higher doses of $\mathrm{Cd}$ produced a significant decrease in the WBC number compared to the control group and to a lower dose of $\mathrm{Cd}(p<0.001, p<0.01$, respectively), while there was no difference in the group receiving the mixture. The change in absolute lymphocyte count had a similar trend, and the $\mathrm{Cd}_{30}$ group exhibited a lower count compared to values from the control and $\mathrm{Cd}_{15}$ groups (both, $p<0.01)$. A lower dose of $\mathrm{Cd}$ also produced a significant decrease in contrast to the control group $(p<0.01)$. Following the administration of $\mathrm{Pb}$, we observed significantly higher absolute neutrophils counts in only the group that received the mixture of toxic metals in contrast to control values $(p<0.05)$, while single $\mathrm{Pb}$ treatment did not produce any changes in WBC count.

In all experimental groups, we noticed a decreasing trend in RBC, HGB, and HCT levels compared to values obtained from the control group, yet there was no difference between the treated groups. 
The most pronounced effects were observed in the $\mathrm{Cd}_{30}$ group and $\mathrm{Cd}_{15}+\mathrm{Pb}_{150}$ group (for all three parameters, $p<0.001)$. Significant changes in $\mathrm{MCH}$ were noticed in both Cd-treated groups $\left(\mathrm{Cd}_{15}\right.$ group and $\mathrm{Cd}_{30}$ group) when compared to the controls. Neither MCV nor MCHC was affected by the treatment.

Platelet count was significantly increased in the $\mathrm{Cd}_{15}$ group $(p<0.01)$, but decreased in the $\mathrm{Cd}_{30}$ group, in contrast to control. The $\mathrm{Pb}$ given as a single chemical achieved a statistically significant decrease in the PLT count compared to the control group, while $\mathrm{Pb}$ given in the mixture only produced a reduction in PLT when compared to the same single dose of $\mathrm{Cd}(p<0.001)$. Observed hematological parameters are shown in Table 1.

Table 1. Effect of $\mathrm{Cd}$ or/and $\mathrm{Pb}$ on hematological parameters in rats after acute exposure.

\begin{tabular}{|c|c|c|c|c|c|}
\hline & Control Group & $\mathrm{Cd}_{15}$ Group & $\mathrm{Cd}_{30}$ Group & $\mathrm{Pb}_{150}$ Group & $\mathrm{Cd}_{15}+\mathrm{Pb}_{150}$ Group \\
\hline $\operatorname{WBC}\left(10^{9} / \mathrm{L}\right)^{1}$ & $3.85 \pm 0.68$ & $3.56 \pm 0.53$ & $2.36 \pm 0.32 * * *++$ & $4.08 \pm 0.75$ & $3.97 \pm 0.66$ \\
\hline \multirow{2}{*}{$\begin{array}{l}\text { Lymphocyte } \\
\left(10^{9} / \mathrm{L}\right)^{2}\end{array}$} & 2.58 & $1.84^{* *}$ & $1.15^{* *+\dagger}$ & 2.54 & 2.22 \\
\hline & $1.84-2.94$ & $1.36-2.11$ & $1.01-1.16$ & $2.18-2.77$ & $1.44-2.69$ \\
\hline \multirow{2}{*}{$\begin{array}{l}\text { Neutrophils } \\
\left(10^{9} / \mathrm{L}\right)^{2}\end{array}$} & 1.02 & 1.21 & 0.88 & 1.27 & $1.23 *$ \\
\hline & $0.80-1.41$ & $0.73-1.99$ & $0.75-1.18$ & $0.81-1.43$ & $0.95-2.14$ \\
\hline $\operatorname{RBC}\left(10^{12} / \mathrm{L}\right)^{1}$ & $6.91 \pm 0.25$ & $5.61 \pm 0.98^{* * *}$ & $5.05 \pm 0.61^{* * *}$ & $5.74 \pm 0.67^{* *}$ & $5.19 \pm 0.74^{* * *}$ \\
\hline \multirow{2}{*}{$\operatorname{HGB}(\mathrm{g} / \mathrm{L})^{2}$} & 148.0 & $139.0 *$ & $117.5^{* * *}$ & $126.5^{*}$ & $117.0^{* * *}$ \\
\hline & $143.0-161.0$ & $105.0-154.0$ & $104.0-128.0$ & 118.0-153.0 & $94.0-127.0$ \\
\hline \multirow{2}{*}{$\mathrm{HCT}(\mathrm{L} / \mathrm{L})^{2}$} & 0.401 & $0.343 *$ & $0.314^{* * *}$ & 0.336 * & $0.303^{* * *}$ \\
\hline & $0.380-0.410$ & $0.250-0.410$ & $0.260-0.340$ & $0.300-0.420$ & $0.210-0.340$ \\
\hline \multirow{2}{*}{$\operatorname{MCV}(\mathrm{fL})^{2}$} & 58.0 & 58.0 & 60.5 & 60.0 & 58.0 \\
\hline & $56.0-61.0$ & $57.0-62.0$ & $56.0-69.9$ & $56.0-63.0$ & $56.0-59.0$ \\
\hline \multirow{2}{*}{$\mathrm{MCH}(\mathrm{pg})^{2}$} & 21.0 & $23.5^{* *}$ & $23.0 *$ & 22.5 & 22.0 \\
\hline & $20.0-23.0$ & $22.0-25.0$ & $22.0-26.0$ & $22.0-24.0$ & $21.0-26.0$ \\
\hline \multirow{2}{*}{$\operatorname{MCHC}(\mathrm{g} / \mathrm{L})^{2}$} & 370.0 & 398.0 & 386.5 & 383.0 & 379.0 \\
\hline & $361.0-390.0$ & $379.0-420.0$ & $349.0-409.0$ & $361.0-397.0$ & $372.0-447.0$ \\
\hline $\operatorname{PLT}\left(10^{9} / \mathrm{L}\right)^{1}$ & $571.25 \pm 43.03$ & $701.00 \pm 40.30 * *$ & $341.50 \pm 92.36^{* * *++\dagger}$ & $449.50 \pm 100.60^{* *}$ & $525.00 \pm 53.86^{t++}$ \\
\hline
\end{tabular}

1 Values are presented as means \pm standard deviation. ${ }^{2}$ Values are presented as medians and ranges. $\mathrm{WBC}=$ white blood cell count; $\mathrm{RBC}=$ red blood cell count; $\mathrm{HGB}=$ hemoglobin; $\mathrm{HCT}=$ hematocrit; $\mathrm{MCV}=$ mean corpuscular volume; $\mathrm{MCH}=$ mean corpuscular hemoglobin; $\mathrm{MCHC}=$ mean corpuscular hemoglobin concentration; $\mathrm{PLT}=$ platelet count. Parameters that were not influenced by $\mathrm{Cd}$ and $\mathrm{Pb}$ treatment are not listed. Statistically significant differences $(p<0.05)$ compared to control group are indicated by ${ }^{*},{ }^{\dagger} \mathrm{Cd}_{15}$ group, $\ddagger \mathrm{Pb}_{150}$ group. Statistical evaluation was performed using one-way ANOVA and Kruskal-Wallis nonparametric test followed by

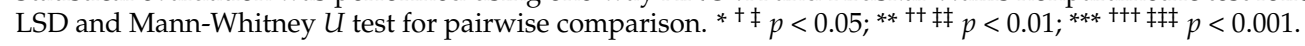

\subsection{Biochemical Assays}

Acute exposure to the investigated toxic metals administered alone or in mixture form resulted in the altered profile of some biochemical parameters. All experimental groups had lower concentrations of urea compared to the control group, while there was a slight increase in creatinine levels in all experimental groups, only reaching significance in the $\mathrm{Cd}_{30}$ group and $\mathrm{Pb}_{150}$ group when compared to the controls ( $p<0.01, p<0.05$, respectively). Total proteins and albumin levels were lower after exposure to a mixture relative to the control group $(p<0.01, p<0.05$, respectively). Additionally, mixture treatment caused a lower proteins level $(p<0.05)$ in contrast to the $\mathrm{Pb}_{150}$ group. An elevated level of direct bilirubin was observed in the $\mathrm{Pb}_{150}$ group in comparison to the control, while total bilirubin was at least slightly increased in all experimental groups, with only the values from the $\mathrm{Cd}_{15}$ group and $\mathrm{Cd}_{30}$ group reaching statistical significance compared to the control. Exposure to either toxic metal did not affect the levels of uric acid across all treatment groups.

All experimental groups had lower concentrations of serum iron compared to the control $(p<0.001)$, without any difference among dosing groups. Change in calcium levels was towards reduction, but statistical significance was only achieved in groups that received $\mathrm{Pb}$, with a more pronounced effect in the mixture $(p<0.01)$. A similar trend was noticed for magnesium levels, with reductions not only after $\mathrm{Pb}$ administration, but also following the dose of $30 \mathrm{mg} \mathrm{Cd} / \mathrm{kg}$ b.w. 
Furthermore, differences within the groups were not observed for either calcium or magnesium. Phosphorus levels were only significantly lower after the administration of $30 \mathrm{mg} / \mathrm{kg} \mathrm{b.w}$. Cd when compared to the control $(p<0.05)$. Changes in chloride levels were observed in the group receiving $\mathrm{Pb}$ as a single metal and in a group receiving a higher $\mathrm{Cd}$ dose when compared to the untreated group, whereas after the application of the mixture, chlorine levels were significantly different, but only for the individual $\mathrm{Pb}$ dose group $(p<0.01)$. Observed biochemical parameters are shown in Table 2.

Table 2. Effect of $\mathrm{Cd}$ or/and $\mathrm{Pb}$ on biochemical parameters in rat serum after acute exposure.

\begin{tabular}{|c|c|c|c|c|c|}
\hline & Control Group & $\mathrm{Cd}_{15}$ Group & $\mathrm{Cd}_{30}$ Group & $\mathrm{Pb}_{150}$ Group & $\mathrm{Cd}_{15}+\mathrm{Pb}_{150}$ Group \\
\hline $\mathrm{BUN}(\mathrm{mmol} / \mathrm{L})^{1}$ & $10.72 \pm 1.02$ & $8.56 \pm 0.82 * * *$ & $8.76 \pm 1.08$ ** & $8.76 \pm 1.12 * *$ & $9.08 \pm 1.13^{* *}$ \\
\hline CRE $(\mu \mathrm{mol} / \mathrm{L})^{2}$ & $\begin{array}{c}42.45 \\
39.5-43.4\end{array}$ & $\begin{array}{c}44.75 \\
35.5-53.4\end{array}$ & $\begin{array}{c}45.45^{* *} \\
42.8-53.4\end{array}$ & $\begin{array}{c}43.40 * \\
41.4-46.7\end{array}$ & $\begin{array}{c}43.40 \\
40.5-46.1\end{array}$ \\
\hline $\mathrm{TP}(\mathrm{g} / \mathrm{L})^{2}$ & $\begin{array}{c}59.0 \\
53.4-63.3\end{array}$ & $\begin{array}{c}60.3 \\
45.3-74.2\end{array}$ & $\begin{array}{c}61.8 \\
53.4-64.9\end{array}$ & $\begin{array}{c}59.5 \\
55.1-66.8\end{array}$ & $\begin{array}{c}52.4^{* *} \ddagger \\
48.7-58.0\end{array}$ \\
\hline $\operatorname{ALB}(g / L)^{2}$ & $\begin{array}{c}32.1 \\
29.4-35.7\end{array}$ & $\begin{array}{c}28.8 \\
22.5-36.6\end{array}$ & $\begin{array}{c}30.3 \\
27.0-33.4\end{array}$ & $\begin{array}{c}30.7 \\
29.9-32.1\end{array}$ & $\begin{array}{c}28.8 * \\
26.3-32.0\end{array}$ \\
\hline $\mathrm{DB}(\mu \mathrm{mol} / \mathrm{L})^{2}$ & $\begin{array}{c}0.4 \\
0.3-0.5\end{array}$ & $\begin{array}{c}0.45 \\
0.2-0.5\end{array}$ & $\begin{array}{c}0.4 \\
0.3-0.6\end{array}$ & $\begin{array}{c}0.7^{* *} \\
0.7-0.9\end{array}$ & $\begin{array}{c}0.4 \text { 㧊 } \\
0.4-0.6\end{array}$ \\
\hline $\mathrm{TB}(\mu \mathrm{mol} / \mathrm{L})^{1}$ & $2.04 \pm 0.16$ & $2.56 \pm 0.33^{* *}$ & $2.38 \pm 0.38 *$ & $2.24 \pm 0.16$ & $2.18 \pm 0.14^{\dagger}$ \\
\hline $\mathrm{Fe}(\mu \mathrm{mol} / \mathrm{L})^{1}$ & $61.7 \pm 11.4$ & $27.5 \pm 8.8^{* * *}$ & $21.6 \pm 5.8^{* * *}$ & $36.3 \pm 10.5^{* * *}$ & $31.4 \pm 6.3^{* * *}$ \\
\hline $\mathrm{Ca}(\mathrm{mmol} / \mathrm{L})^{2}$ & $\begin{array}{c}2.93 \\
2.5-3.2\end{array}$ & $\begin{array}{c}2.73 \\
2.2-3.2\end{array}$ & $\begin{array}{c}2.65 \\
2.5-3.1\end{array}$ & $\begin{array}{c}2.65 * \\
2.5-2.9\end{array}$ & $\begin{array}{l}2.48^{* *} \\
2.2-2.7\end{array}$ \\
\hline $\mathrm{Mg}(\mathrm{mmol} / \mathrm{L})^{2}$ & $\begin{array}{c}1.70 \\
1.5-1.9\end{array}$ & $\begin{array}{c}1.55 \\
1.1-2.2\end{array}$ & $\begin{array}{c}1.30 * \\
1.3-1.8\end{array}$ & $\begin{array}{l}1.35^{* * *} \\
1.0-1.5\end{array}$ & $\begin{array}{l}1.30 * * * \\
1.1-1.5\end{array}$ \\
\hline $\mathrm{P}(\mathrm{mmol} / \mathrm{L})^{2}$ & $\begin{array}{c}3.05 \\
3.0-3.4\end{array}$ & $\begin{array}{c}2.87 \\
2.6-4.4\end{array}$ & $\begin{array}{c}2.71 * \\
2.4-3.3\end{array}$ & $\begin{array}{c}3.15 \\
2.9-3.2\end{array}$ & $\begin{array}{c}3.05 \\
2.1-3.4\end{array}$ \\
\hline $\mathrm{Cl}(\mathrm{mmol} / \mathrm{L})^{2}$ & $\begin{array}{c}105.0 \\
102.0-109.0\end{array}$ & $\begin{array}{c}110.5 \\
102.0-118.0\end{array}$ & $\begin{array}{c}108.5 * \\
105.0-116.0\end{array}$ & $\begin{array}{c}113.0 * * * \\
108.0-118.0\end{array}$ & $\begin{array}{c}106.0 \text { 㧊 } \\
100.0-109.0\end{array}$ \\
\hline
\end{tabular}

${ }^{1}$ Values are presented as means \pm standard deviation. ${ }^{2}$ Values are presented as medians and ranges. Blood urea nitrogen (BUN), creatinine (CRE), total serum proteins (TP), albumin (ALB), direct bilirubin (DB), total bilirubin $(\mathrm{TB})$, iron $(\mathrm{Fe})$, calcium $(\mathrm{Ca})$, magnesium $(\mathrm{Mg})$, inorganic phosphorus $(\mathrm{P})$, chloride $(\mathrm{Cl})$. Parameters that were not influenced by $\mathrm{Cd}$ and $\mathrm{Pb}$ treatment are not listed. Statistically significant differences $(p<0.05)$ compared to control group are indicated by ${ }^{*},{ }^{\dagger} \mathrm{Cd}_{15}$ group, ${ }^{\ddagger} \mathrm{Pb}_{150}$ group. Statistical evaluation was performed using one-way ANOVA and Kruskal-Wallis nonparametric test followed by LSD and Mann-Whitney $U$ test for pairwise comparison.

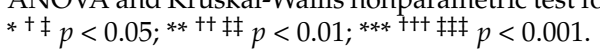

All experimental groups exhibited a downward trend in ALT activity, and a statistically significant effect at the higher dose of $\mathrm{Cd}(p<0.05)$, as well as in both groups receiving $\mathrm{Pb}$, when compared to the controls. On the other hand, only mixture administration reduced AST activity $(p<0.05)$ compared to $\mathrm{Pb}$ given alone. Both $\mathrm{Cd}$ doses decreased ALP activity compared to the control group $(p<0.001)$, and higher Cd doses significantly decreased ALP activity $(p<0.05)$ compared to lower Cd doses. Similarly, experimental groups receiving $\mathrm{Pb}$ and the mixture showed a decrease in ALP activity relative to the control group $(p<0.001)$. LDH activity was decreased after $30 \mathrm{mg} / \mathrm{kg}$ b.w. Cd administration in contrast to the untreated controls and the $\mathrm{Cd}_{15}$ group $(p<0.05, p<0.01$, respectively), while changes in AMY activity were not observed. Investigated enzyme activities in rat serum are shown in Figure 3. 


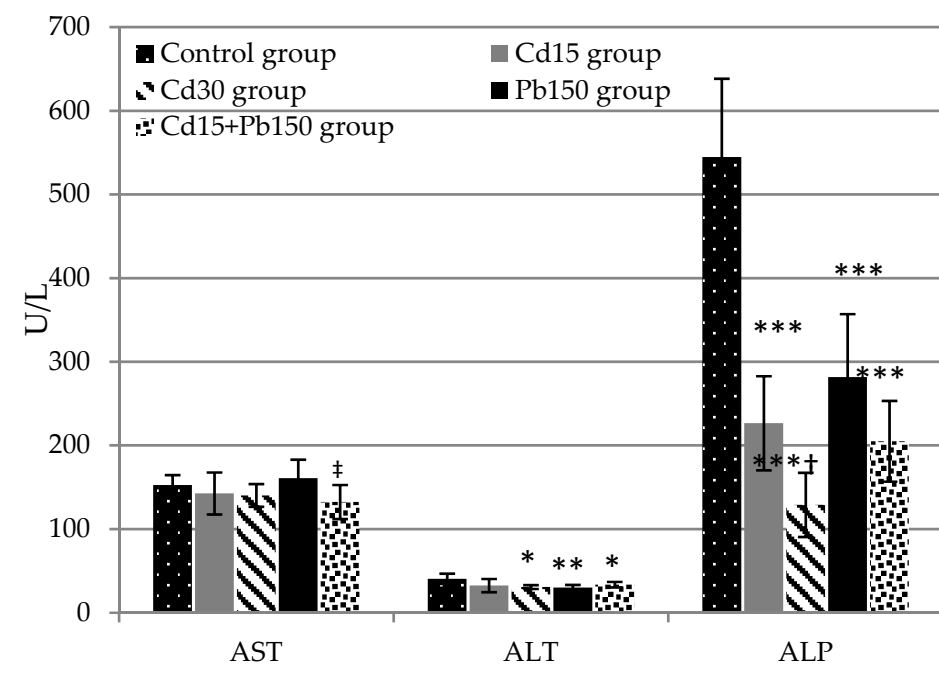

(a)

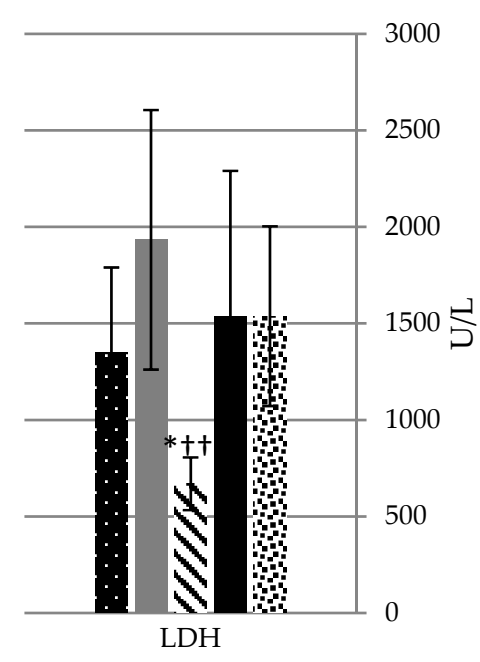

(b)

Figure 3. Effect of $\mathrm{Cd}$ or/and $\mathrm{Pb}$ on serum enzyme activities in rats after acute exposure. Aspartate aminotransferase (AST), alanine aminotransferase (ALT), and alkaline phosphatase (ALP) are represented on panel (a), while lactate dehydrogenase (LDH) on panel (b). Parameters that were not influenced by $\mathrm{Cd}$ and $\mathrm{Pb}$ treatment are not listed. Values are presented as means and S.D. Statistically significant differences $(p<0.05)$ compared to control group are indicated by ${ }^{*},{ }^{+} \mathrm{Cd}_{15}$ group,, $\mathrm{Pb}_{150}$ group. Statistical evaluation was performed using one-way ANOVA followed by LSD post-hoc test for

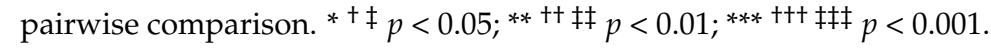

\subsection{Redox Status}

Blood MDA level was increased after the administration of $30 \mathrm{mg} / \mathrm{kg}$ b.w. Cd, but only when compared to the lower $\mathrm{Cd}$ dose $(p<0.05)$. After exposure to the mixture, both MDA and AOPP blood levels were increased compared to groups receiving single metal. Additionally, mixture treatment induced a significant elevation of blood AOPP compared to control values $(p<0.001)$. We did not observe any toxic metal-induced changes in the overall levels of SH-groups and PAB in blood. Liver AOPP concentration was increased in all experimental groups receiving a single metal, yet we did not observe any differences between these groups. AOPP levels after mixture treatment were similar to control values, but were observed to be lower when compared to a single $\mathrm{Cd}$ dose. Other redox parameters, such as MDA, SH-groups, and SOD activity, were not altered in rat liver after acute exposure to toxic metals. The higher dose of $\mathrm{Cd}$ produced significant increases in kidney MDA levels when compared to the group treated with a lower Cd dose $(p<0.05)$. Elevated MDA levels were observed in both $\mathrm{Pb}$ treatment groups, with more pronounced effects after treatment with the mixture compared to the controls $(p<0.001)$. Furthermore, mixture administration produced a significant elevation in MDA concentration in the kidney compared to a single Cd dose $(p<0.01)$. AOPP levels, SH-groups, and SOD activity remained unchanged in kidneys after toxic metals treatments. Observed redox parameters in rat blood, liver, and kidneys are presented in Table 3. 
Table 3. Redox parameters in rat blood, liver, and kidney after $\mathrm{Cd}$ or/and $\mathrm{Pb}$ acute exposure.

\begin{tabular}{|c|c|c|c|c|c|c|}
\hline & & Control Group & $\mathrm{Cd}_{15}$ Group & $\mathrm{Cd}_{30}$ Group & $\mathrm{Pb}_{150}$ Group & $\mathrm{Cd}_{15}+\mathrm{Pb}_{150}$ Group \\
\hline \multirow{8}{*}{ Blood } & \multirow{2}{*}{$\operatorname{MDA}(\mu \mathrm{mol} / \mathrm{L})$} & 2.23 & 1.94 & $2.66^{+}$ & 2.10 & $2.41^{\dagger \ddagger}$ \\
\hline & & $1.99-3.68$ & $1.49-2.82$ & $2.17-3.13$ & $1.62-2.46$ & $2.16-3.21$ \\
\hline & \multirow{2}{*}{$\begin{array}{l}\mathrm{AOPP}(\mu \mathrm{mol} / \mathrm{g} \\
\text { protein })\end{array}$} & 1.84 & 1.40 * & 1.97 & 2.34 & 13.53 *** †+十 fł‡ \\
\hline & & $1.67-2.19$ & $1.20-1.95$ & $1.26-3.68$ & $1.53-6.04$ & 9.94-16.59 \\
\hline & \multirow{2}{*}{$\begin{array}{l}\text { SH-groups } \\
(\mathrm{mmol} / \mathrm{L})\end{array}$} & 0.12 & 0.16 & 0.13 & 0.16 & 0.18 \\
\hline & & $0.08-0.21$ & $0.10-0.22$ & $0.10-0.13$ & $0.13-0.26$ & $0.13-0.27$ \\
\hline & \multirow{2}{*}{ PAB (HCU) } & 136.6 & 186.2 & 189.6 & 191.0 & 128.6 \\
\hline & & 105.3-181.6 & $169.0-215.9$ & $144.3-203.5$ & $133.6-201.4$ & $87.2-150.0$ \\
\hline \multirow{8}{*}{ Liver } & \multirow{2}{*}{$\begin{array}{l}\text { MDA ( } \mu \mathrm{mol} / \mathrm{mg} \\
\text { protein) }\end{array}$} & 80.1 & 75.76 & 104.75 & 77.15 & 76.59 \\
\hline & & 56.77-95.52 & $64.08-89.08$ & $68.64-124.80$ & 36.59-101.19 & $62.66-98.31$ \\
\hline & \multirow{2}{*}{$\begin{array}{l}\mathrm{AOPP}(\mu \mathrm{mol} / \mathrm{g} \\
\text { protein })\end{array}$} & 83.16 & $234.84^{* * *}$ & $201.66^{* * *}$ & $178.99 *$ & $81.42^{+\dagger}$ \\
\hline & & $35.82-166.36$ & $172.37-252.13$ & 179.94-324.36 & $114.81-228.23$ & $38.05-194.69$ \\
\hline & \multirow{2}{*}{$\begin{array}{c}\text { SH groups } \\
\text { (mmol/g protein) }\end{array}$} & 0.31 & 0.31 & 0.30 & 0.31 & 0.27 \\
\hline & & $0.25-0.33$ & $0.22-0.38$ & $0.25-0.40$ & $0.20-0.39$ & $0.15-0.36$ \\
\hline & \multirow{2}{*}{ SOD (U/g) } & 56.92 & 53.56 & 52.8 & 55.70 & 52.45 \\
\hline & & $52.07-60.82$ & $45.54-57.35$ & $048.47-59.67$ & $47.77-60.65$ & $51.48-63.25$ \\
\hline \multirow{8}{*}{ Kidneys } & \multirow{2}{*}{$\begin{array}{l}\text { MDA }(\mu \mathrm{mol} / \mathrm{mg} \\
\text { protein })\end{array}$} & 209.42 & 171.94 & $237.65^{\dagger}$ & 283.88 * & $273.15^{* * *+十}$ \\
\hline & & $132.68-232.39$ & $143.99-253.74$ & $194.81-397.13$ & $197.42-328.57$ & $233.25-321.88$ \\
\hline & \multirow{2}{*}{$\begin{array}{l}\mathrm{AOPP}(\mu \mathrm{mol} / \mathrm{g} \\
\text { protein })\end{array}$} & 273.68 & 255.58 & 286.65 & 297.75 & 273.79 \\
\hline & & $153.97-341.22$ & $206.36-317.21$ & $250.53-360.61$ & $231.56-368.82$ & $226.38-362.08$ \\
\hline & \multirow{2}{*}{$\begin{array}{c}\text { SH groups } \\
\text { (mmol/g protein) }\end{array}$} & 0.27 & 0.25 & 0.25 & 0.24 & 0.27 \\
\hline & & $0.18-0.34$ & $0.17-0.39$ & $0.21-0.35$ & $0.22-0.30$ & $0.17-0.31$ \\
\hline & \multirow{2}{*}{$\operatorname{SOD}(\mathrm{U} / \mathrm{g})$} & 62.31 & 57.02 & 52.56 & 61.83 & 60.65 \\
\hline & & $37.84-74.04$ & $46.90-63.07$ & $46.88-70.01$ & $50.54-73.51$ & $37.58-76.60$ \\
\hline
\end{tabular}

Values are presented as medians and ranges. Malondialdehyde (MDA), advanced oxidation protein products level (AOPP), total thiol (SH) groups level, prooxidative-antioxidative balance (PAB) expressed in arbitrary hydrogen peroxide complementary units (HCU), superoxide dismutase activity (SOD). Observed parameters are expressed on wet tissues. Parameters that were not influenced by $\mathrm{Cd}$ and $\mathrm{Pb}$ treatment are not listed. Statistically significant differences $(p<0.05)$ compared to control group are indicated by ${ }^{*},{ }^{\dagger} \mathrm{Cd}_{15}$ group, ${ }^{\ddagger} \mathrm{Pb}_{150}$ group. Statistical evaluation was performed using the Kruskal-Wallis nonparametric test followed by Mann-Whitney $U$ test for pairwise comparison. ${ }^{* \dagger \ddagger} p<0.05 ; * *++\neq \ddagger p<0.01 ; * * *+++$ 拉 $p<0.001$.

Total antioxidative status, total oxidative status, and oxidative stress index in rat plasma, liver, and kidneys are presented in Figure 4. Blood TOS levels were increased in all experimental groups exposed to a single metal, but the increase was only significant in the $\mathrm{Cd}_{30}$ group and $\mathrm{Pb}_{150}$ group compared to control values. TAS content was inversely affected by the type of metal treatment. Groups receiving a single metal had lower blood TAS levels compared to the control, but TAS levels were significantly higher in the mixture group compared to groups treated with a single metal. The degree of oxidative stress in blood was calculated as the ratio between TOS and TAS, which exhibited an upward trend after exposure to individual metals. Only in the highest dose, the $\mathrm{Cd}_{30}$ and $\mathrm{Pb}_{150}$ groups, did this trend reach statistical significance. The most robust effect in the liver was observed after exposure to a single $\mathrm{Pb}$ dose $(p<0.01)$, resulting in a reduction in TAS content compared to the control group. Moreover, the highest liver OSI index value was noticed in the $\mathrm{Pb}_{150}$ group, which was in line with the lowered TAS value. No statistically significant changes were observed in kidney TOS and TAS levels compared to the control group, hence the OSI index also remained unchanged. 


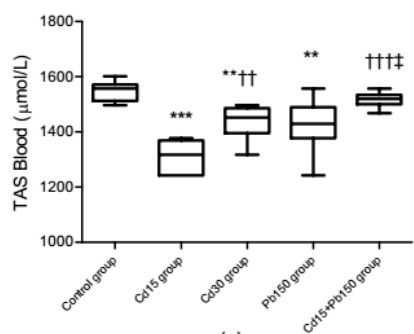

(a)
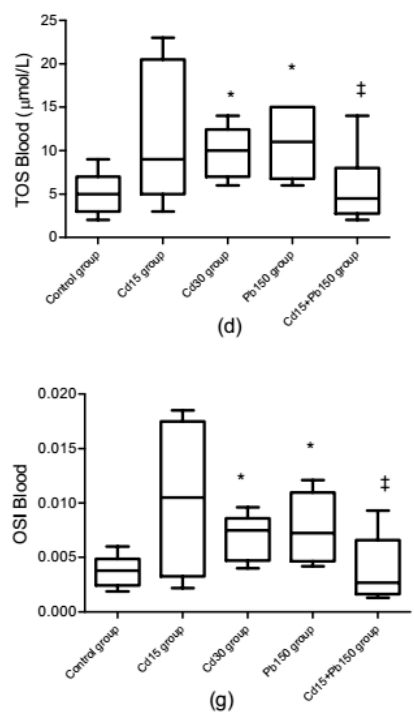

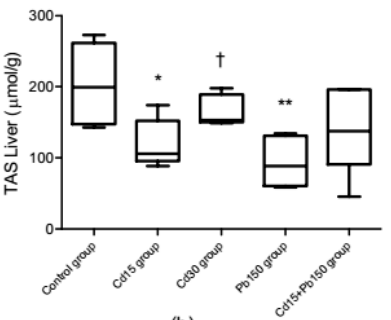

(b)

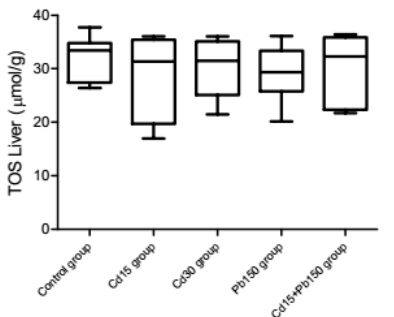

(e)

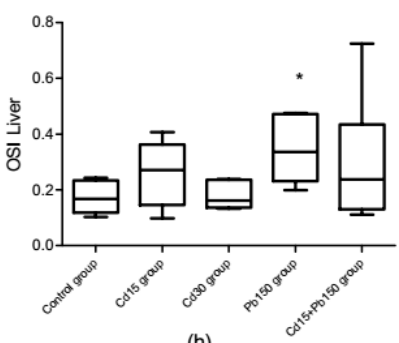

(h)

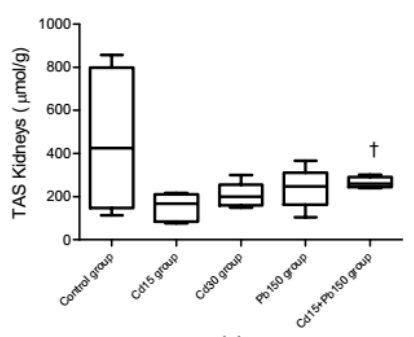

(c)
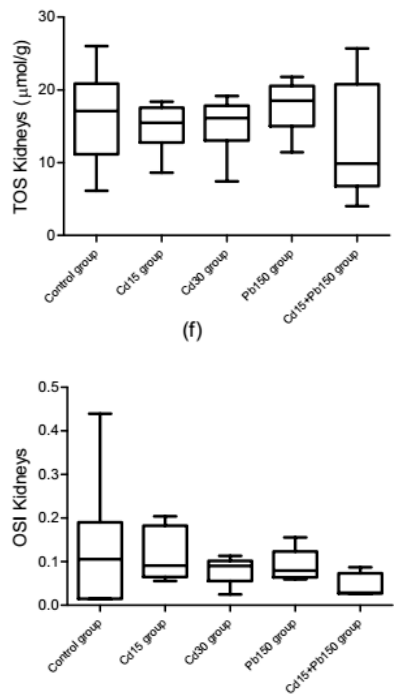

Figure 4. Effect of $\mathrm{Cd}$ or/and $\mathrm{Pb}$ on total antioxidative status (TAS, panel $(\mathbf{a}-\mathbf{c})$ ), total oxidative status (TOS, panel $(\mathbf{d}-\mathbf{f})$ ), and oxidative stress index (OSI, panel $(\mathbf{g}-\mathbf{i})$ ) values in rat blood, liver, and kidney after acute exposure. Levels of TAS and TOS are expressed on wet tissues. The box represents interquartile range (25-75th percentile), the line within the box represents median value, and ends of the whiskers represent the minimum and maximum values within the group. Statistically significant differences $(p<0.05)$ compared to control group are indicated by ${ }^{*},{ }^{+} \mathrm{Cd}_{15}$ group, $\ddagger \mathrm{Pb}_{150}$ group. Statistical evaluation was performed using the Kruskal-Wallis nonparametric test followed by

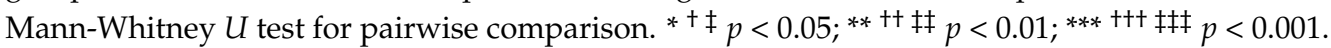

The obtained redox parameters after acute exposure with $\mathrm{Cd}$ or/and $\mathrm{Pb}$ were used to calculate three scores: a score of oxidative damage (DS), a score of antioxidative defenses (protection score, PS), and the so-called OXY-score (as a global score of oxidative balance). The protection score was calculated as an average of standardized antioxidant variables by calculating $Z$ scores (TAS, SOD, and SH-groups), while the damage score was calculated as an average of standardized prooxidant factors by calculating $Z$ scores (TOS, PAB, MDA, and AOPP). The OXY-score was calculated by subtracting the PS from the DS using the equation given by Veglia et al. [54]. The OXY-score is approximately equal to zero when the sum of all the analytes is approximately the average of normal values, or the high level of damage markers is compensated for by high levels of antioxidant protection [54]. After evaluating the obtained results for calculating the oxidative damage score in all three investigated mediums, DS was positively correlated with different doses of $\mathrm{Cd}$, but a significant correlation was only observed with a higher $\mathrm{Cd}$ dose. Additionally, a significant correlation was detected in the $\mathrm{Pb}_{150}$ group. The parameters used to calculate antioxidative defenses had a lower trend in all investigated groups, and the overall protection score was lower than the control, but these changes were not significant. Overproduction of pro-oxidant versus antioxidative protection in the $\mathrm{Cd}_{30}$ group and $\mathrm{Pb}_{150}$ group resulted in a high OXY-score value, indicating higher oxidative damage in these two experimental groups. Observed oxidative stress scores are presented in Table 4. 
Table 4. Oxidative stress score after acute exposure to $\mathrm{Cd}$ or/and $\mathrm{Pb}$ in rats.

\begin{tabular}{cccccc}
\hline & Control Group & $\mathbf{C d}_{\mathbf{1 5}}$ Group & $\mathbf{C d}_{\mathbf{3 0}}$ Group & $\mathbf{P b}_{\mathbf{1 5 0}}$ Group & $\mathbf{C d}_{\mathbf{1 5}}+\mathbf{P b}_{\mathbf{1 5 0}}$ Group \\
\hline Damage score & $-0.083 \pm 0.49$ & $0.088 \pm 0.51$ & $0.526 \pm 0.26^{*}$ & $0.485 \pm 0.24^{*}$ & $-0.254 \pm 0.39 \ddagger$ \\
Protection score & $-0.038 \pm 0.34$ & $-0.37 \pm 0.56$ & $-0.29 \pm 0.24$ & $-0.11 \pm 0.37$ & $-0.22 \pm 0.63$ \\
OXY-score & $-0.045 \pm 0.58$ & $0.46 \pm 0.89$ & $0.81 \pm 0.39 *$ & $0.77 \pm 0.30 *$ & $-0.037 \pm 0.80^{*}$ \\
\hline
\end{tabular}

Values are presented as means \pm standard deviation. Statistically significant differences $(p<0.05)$ compared to control group are indicated by ${ }^{*},{ }^{+} \mathrm{Cd}_{15}$ group,${ }^{\ddagger} \mathrm{Pb}_{150}$ group. Statistical evaluation was performed using one-way ANOVA followed by LSD post-hoc test for pairwise comparison.

\subsection{Bioelements Levels in Tissues}

Experimental groups treated with $15 \mathrm{mg} \mathrm{Cd} / \mathrm{kg}$ b.w. had lower blood Cu levels in comparison to the controls $(p<0.001)$. After mixture treatment, blood $\mathrm{Cu}$ levels were in line with the control and $\mathrm{Pb}_{150}$ group, but higher than the $\mathrm{Cd}_{15}$ group $(p<0.001)$. On the other hand, the most prominent decrease of blood $\mathrm{Zn}$ level was observed after exposure to $30 \mathrm{mg} \mathrm{Cd} / \mathrm{kg}$ b.w. in contrast to the control and $\mathrm{Cd}_{15}$ group ( $p<0.05, p<0.001$, respectively). Following metal mixture treatment, blood $\mathrm{Zn}$ levels were lower compared to each of the individual metal treatment groups $(p<0.05)$.

Treatment with the higher $\mathrm{Cd}$ dose resulted in a significant elevation in liver $\mathrm{Cu}$ levels over control values $(p<0.01)$. Furthermore, both $\mathrm{Pb}$-treated groups exhibited increased liver $\mathrm{Cu}$ levels, with the most prominent elevation after mixture treatment $(p<0.01)$. Levels of $\mathrm{Zn}$ in the liver were increased after all dose regimes, but $\mathrm{Pb}$ treatments produced the most pronounced one. Namely, in both $\mathrm{Pb}$ groups, we observed a significant elevation in $\mathrm{Zn}$ levels compared to control values $(p<0.001)$.

Both Cd groups $\left(\mathrm{Cd}_{15}\right.$ and $\left.\mathrm{Cd}_{30}\right)$ had lower renal $\mathrm{Zn}$ levels compared to controls $(p<0.001)$. A significant decrease in renal $\mathrm{Zn}$ levels was also observed after $\mathrm{Pb}$ treatments compared to the control. Following administration of the mixture, renal $\mathrm{Zn}$ levels were higher than after single Cd treatment, but similar to the $\mathrm{Pb}_{150}$ group. Bioelement levels in the rat blood, liver, and kidney are presented in Table 5.

Table 5. Levels of $\mathrm{Cu}$ and $\mathrm{Zn}$ in rat blood, liver, and kidney after acute exposure to $\mathrm{Cd}$ or/and $\mathrm{Pb}$.

\begin{tabular}{|c|c|c|c|c|c|c|}
\hline & \multicolumn{2}{|c|}{ Blood } & \multicolumn{2}{|c|}{ Liver } & \multicolumn{2}{|c|}{ Kidney } \\
\hline & $\mathrm{Cu}(\mu \mathrm{mol} / \mathrm{L})$ & $\mathrm{Zn}(\mu \mathrm{mol} / \mathrm{L})$ & $\mathrm{Cu}(\mu \mathrm{mol} / \mathrm{kg})$ & $\mathrm{Zn}(\mu \mathrm{mol} / \mathrm{kg})$ & $\mathrm{Cu}(\mu \mathrm{mol} / \mathrm{kg})$ & $\mathrm{Zn}(\mu \mathrm{mol} / \mathrm{kg})$ \\
\hline Control group & $22.10 \pm 1.81$ & $87.76 \pm 3.24$ & $50.74 \pm 2.80$ & $462.77 \pm 57.37$ & $96.92 \pm 10.39$ & $374.18 \pm 38.14$ \\
\hline $\mathrm{Cd}_{15}$ group & $16.09 \pm 1.22 * * *$ & $93.19 \pm 8.61$ & $57.60 \pm 5.58$ & $585.16 \pm 90.11^{* *}$ & $79.27 \pm 4.06$ & $299.70 \pm 25.88^{* * *}$ \\
\hline $\mathrm{Cd}_{30}$ group & $20.00 \pm 2.34^{t+}$ & $74.20 \pm 15.81 *++t$ & $65.08 \pm 10.48^{* *}$ & $576.49 \pm 43.11 *$ & $88.27 \pm 21.02$ & $310.47 \pm 12.89^{* * *}$ \\
\hline $\mathrm{Pb}_{150}$ group & $20.59 \pm 2.40$ & $92.23 \pm 7.62$ & $63.26 \pm 3.65 *$ & $613.06 \pm 24.48^{* * *}$ & $110.95 \pm 22.11$ & $329.07 \pm 22.95 * *$ \\
\hline $\mathrm{Cd}_{15}+\mathrm{Pb}_{150}$ group & $20.19 \pm 1.53^{t+t}$ & $81.04 \pm 7.34^{\dagger \ddagger}$ & $67.00 \pm 13.17^{* *}$ & $609.78 \pm 102.73^{* * *}$ & $95.42 \pm 11.37$ & $336.67 \pm 24.44 *+$ \\
\hline
\end{tabular}

\subsection{Histopathological Analysis}

Histopathological examination in the liver of control rats showed normal architecture (Figure 5a). The $\mathrm{Cd}_{15}$ group cross-section showed very lightly dilated sinusoids with lymphocytic infiltrate in the portal spaces of the liver (Figure $5 b$ ), while lightly to moderately dilated sinusoids with mixed lymphocytic and neutrophilic infiltrate in the portal spaces were observed in the $\mathrm{Cd}_{30}$ group (Figure $5 \mathrm{c}$ ). Lightly dilated sinusoids with mixed lymphocytic and neutrophilic infiltrate in the portal spaces, around biliary ducts, were observed in the $\mathrm{Pb}_{150}$ group. Additionally, scattered mononuclear cells in sinusoids were present. In zone 1 of the acinus, clear hepatocyte cytoplasm with condensed chromatin in nuclei was observed in the $\mathrm{Pb}_{150}$ group, while venous thrombus was present in only one of the examined tissues (Figure 5d). Treatment with the metal mixture resulted in a pattern of changes observed in the $\mathrm{Pb}$ treatment group, but the changes were more prominent (Figure $5 \mathrm{e}$ ). The cross-section in the kidneys of the control group showed normal architecture, while in all treated groups, acute passive hyperemia without significant pathologic changes was observed. 

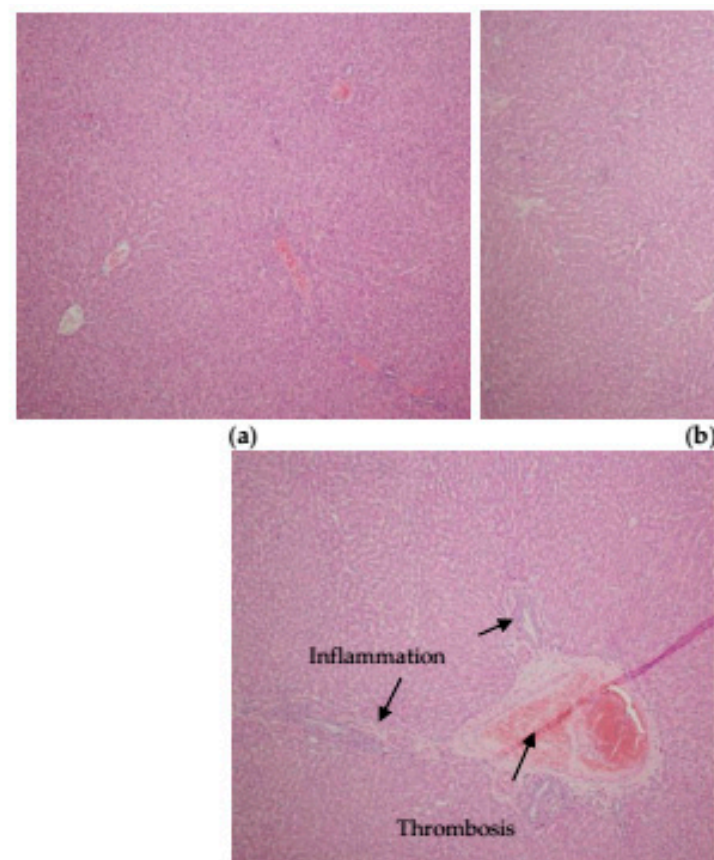

(d)
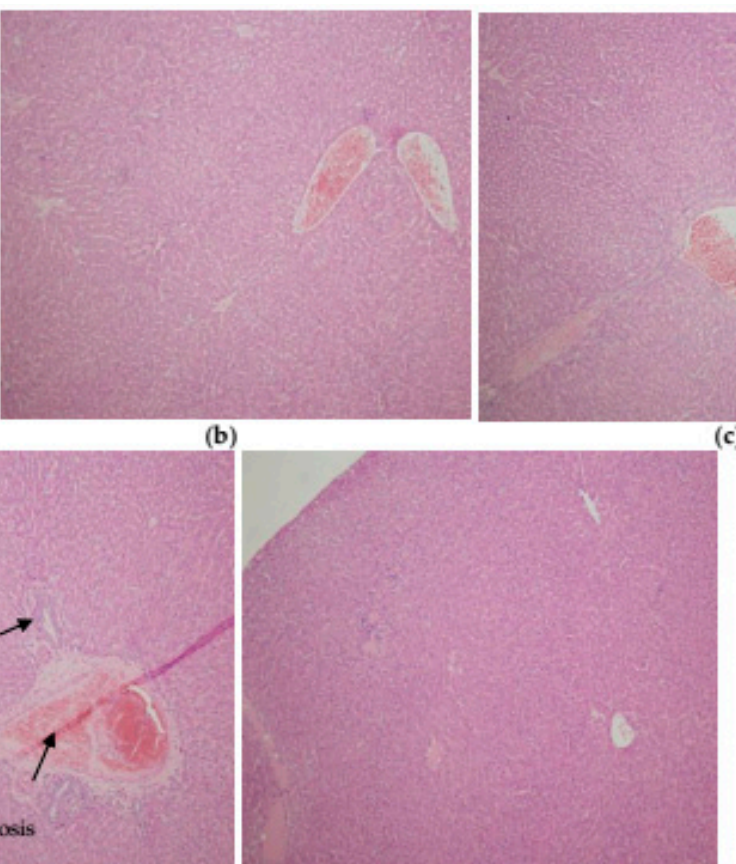

(e)

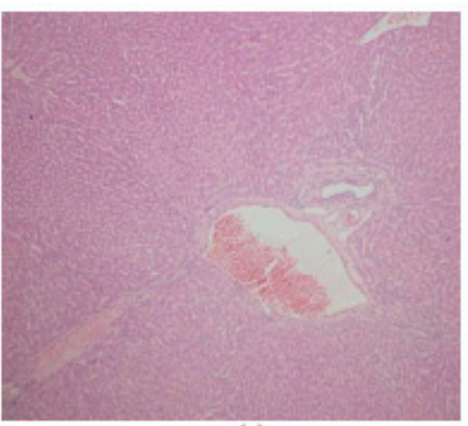

(c)

Figure 5. Effect of $\mathrm{Cd}$ or/and $\mathrm{Pb}$ on microstructures of rats liver after acute exposure. Panel (a): control group; panel (b): $\mathrm{Cd}_{15}$ group; panel (c): $\mathrm{Cd}_{30}$ group; panel (d): $\mathrm{Pb}_{150}$ group; panel (e): $\mathrm{Cd}_{15}+\mathrm{Pb}_{150}$ group.

\section{Discussion}

\subsection{Effects on the Hematopoietic System}

In general, the uptake, distribution, and accumulation of metals in the tissues and organs depend on many factors, such as the metals' characteristics and forms, route, dose and exposure duration, the ability for binding to ligands in the cells, and species sensitivity. The hematopoietic system is one of the most sensitive organs to assess the toxicity. After oral administration, both $\mathrm{Cd}$ and $\mathrm{Pb}$ undergo intestinal absorption and are transported via blood. In the blood, they can be distributed via red blood cells and plasma proteins, mainly albumin $[19,20]$. Both Cd-treated groups had a significantly higher blood $\mathrm{Cd}$ concentration in comparison to the unexposed group, while there were no differences observed between Cd-treatment groups. It could be hypothesized that explanations for this occurrence are limited to gastrointestinal absorption, saturation of $\mathrm{Cd}$ binding sites in the blood, or fast clearance from the blood. On the other hand, analysis of toxic metals in the blood of experimental animals treated with a mixture showed some interesting trends. Namely, blood Cd concentration was lower than in the $\mathrm{Cd}_{15}$ group and it was in line with values we observed in the control group, while blood $\mathrm{Pb}$ concentration was higher than in the corresponding $\mathrm{Pb}$ group. Possible reasons for this observation might be the differences in their bioavailability and their competitive affinity to protein transporters following oral administration with possible antagonism involvement $[55,56]$. A similar observation was noted by Masso et al. [40] using dams that were consuming a solution of $\mathrm{Cd}(10 \mathrm{mg} / \mathrm{L})$ and $\mathrm{Pb}$ $(300 \mathrm{mg} / \mathrm{L})$ from the first day of pregnancy and using the blood taken from pups at day 0 of parturition and the end of lactation. Co-exposure to these toxic metals resulted in diminished blood levels of both metals in contrast to single metal treatment, so the authors suggested a possible antagonistic effect due to gastrointestinal interactions.

Our data showed that both $\mathrm{Cd}$ doses led to absolute lymphopenia, with a more pronounced effect at the higher $\mathrm{Cd}$ dose, where lymphopenia was accompanied by leucopenia. Similar toxic effects of $\mathrm{Cd}$ on lymphocyte count were observed after single $\mathrm{Cd}$ treatment in rats [26,57], after 14 days of $\mathrm{Cd}$ administration in male BALB/c mice [58], and after four-week treatment of Wistar rats with $\mathrm{CdCl}_{2}$ 
via drinking water $[28,59]$. One possible cause of the leucopenia after a single $\mathrm{Cd}$ treatment in our study is that increased destruction of WBC is caused by Cd. We measured high levels of both metals in the spleen and thymus of treated animals after $\mathrm{Cd}$ administration (data are not shown). Lafuente et al. [60] showed high levels of $\mathrm{Cd}$ in the spleen and thymus after oral $\mathrm{CdCl}_{2}$ treatment with doses of 25-100 ppm, as well as decreased B lymphocytes levels in the spleen and thymus, suggesting that direct tissue toxicity is caused by $\mathrm{Cd}$ accumulation. Literature describing the Pb effect is conflicting, with some studies pointing to unchanged WBC status [25,61], leukocytosis [29], and leucopenia [62]. Neutrophilia with moderate leukocytosis observed in this study after mixture administration could be the result of neutrophil release and mobilization under inflammatory IL- 6 and TNF- $\alpha$ from marginal neutrophil pools $[63,64]$.

Administration of either of the toxic metals decreased RBC, HGB, and HCT, with the mixture group showing the largest effects. Namely, the percent decrease in RBC, HGB, and HCT ranged from 10 to $20 \%$ and was observed in both the $\mathrm{Cd}_{15}$ and $\mathrm{Pb}_{150}$ groups, with higher reductions observed in the $\mathrm{Cd}_{15}+\mathrm{Pb}_{150}$ group (20 to $30 \%$ ), corroborating possible additive effects of these metals. Our results are in agreement with other researchers using different animal models, route of exposure, and dose regimes, who also observed RBC, HGB, and HCT reductions $[28,29,57-59,62,65]$. We can assume that the reason for RBC, HGB, and HCT decreasing might be intravascular hemolysis since we measured high values of both metals in the rats' blood in comparison to the control. Acute treatments of investigated toxic metals did not change MCV or MCHC, which is line with other authors $[25,28,59]$. Results from hemoglobin, MCV, and MCHC analysis indicated that both toxic metals may cause normocytic normochromic anemia, even after acute exposure. One of the possible mechanisms of metals-induced hemolysis is oxidative stress induction. Free radical production and lipid peroxidation induced by acute $\mathrm{Cd}$ treatment were implicated in $\mathrm{RBC}$ hemolysis and anemia in a study using Wistar rats treated by a single i.p. injection of $2 \mathrm{mg} / \mathrm{kg}$ b.w. $\mathrm{CdCl}_{2}$ [57]. Additionally, it is well-known that $\mathrm{Pb}$ binds to - $\mathrm{SH}$ groups of different proteins, including enzymes, and subsequently depresses the activity some of them, namely SOD and CAT $[7,10,66]$ and produces a significant MDA and $\mathrm{H}_{2} \mathrm{O}_{2}$ increase in RBC accompanied with reduced glutathione levels [61]. The occurrence of early signs of oxidative stress in our study was observed after mixture treatment, through increased plasma LPO levels expressed as malondialdehyde (MDA). Furthermore, treatment with a higher $\mathrm{Cd}$ dose produced significant MDA elevation. These findings are consistent with our previous work, which revealed a significance increase of MDA levels in plasma after one Cd dose given orally ( $30 \mathrm{mg} / \mathrm{kg} \mathrm{b.w.)}$ and i.p. (1.5 mg/kg b.w.) [42]. Apart from the lipid peroxidation of polyunsaturated membrane lipids, toxic metals can also produce oxidative damage of proteins, leading to AOPP generation, as shown in our previous study in rats [42]. In the present study, mixture treatment generated high plasma AOPP levels in contrast to all other experimental groups. Our results suggest that the effect of combined exposure to $\mathrm{Cd}$ and $\mathrm{Pb}$ resulted in a more pronounced negative effect in plasma versus individual metals, pointing to a possible additive effect. Total antioxidant status expressed as an additive effect of antioxidant molecules [48] was diminished in the blood of all treated groups, while TOS levels (including reactive oxygen metabolites, such as hydrogen peroxide and lipid hydroperoxides) were only elevated after single metal treatment with $30 \mathrm{mg} / \mathrm{kg}$ b.w Cd and $150 \mathrm{mg} / \mathrm{kg}$ b.w. Pb. In line with these results, OSI values were significantly elevated in plasma from the $\mathrm{Cd}_{30}$ group, as well as the $\mathrm{Pb}_{150}$ group, compared to the control. Toxic metal interference with the antioxidant system and resulting increased free radical load are reasons for the trend we observed in TAS and TOS values. Similar observations were noticed by Olisekodiaka et al. [67] and Buha et al. [42].

The two doses of $\mathrm{Cd}$ in the present work elicited contrasting results on platelets values. The lower dose of $\mathrm{Cd}(15 \mathrm{mg} / \mathrm{kg}$ b.w.) produced thrombocytosis in contrast to thrombocytopenia that was achieved with the higher $\mathrm{Cd}$ dose $(30 \mathrm{mg} / \mathrm{kg}$ b.w.). The literature is somewhat conflicting, with some studies pointing to unchanged levels of PLT after acute or subacute treatment $[26,68]$, and others showing a decrease in PLT account $[28,57,59]$. Thrombocytosis observed following administration of the lower Cd dose may be the result of inflammation, which is supported by the results from the WBC 
count, or as reactive thrombocytosis, which is transient and returns to normal after removal of the toxicant. Administration of the higher $\mathrm{Cd}$ dose or the single $\mathrm{Pb}$ dose resulted in thrombocytopenia. As we have previously mentioned, high concentrations of both metals were measured in the spleen (unpublished data), thus direct toxic effects of these metals on PLTs in the spleen represent a mechanism which explains the effects we observed. Interestingly, a mixture of $\mathrm{Cd}$ and $\mathrm{Pb}$ led to an attenuated effect of both metals given as single chemicals, which resulted in platelet values similar to the control group. In support of these findings, we have observed increasing spleen body mass in the $\mathrm{Cd}_{30}$ and $\mathrm{Pb}_{150}$ group, while it was not changed in the mixture group (data are not shown). Similar results with no changes in platelet count were observed in sub-chronic mixture studies cared out by Yuan et al. [24] and Cobbina et al. [25]. This finding suggests a possible antagonistic interaction of these two metals on the levels of PLT count.

\subsection{Effects on Liver}

In the present study, a significantly increased accumulation of $\mathrm{Cd}$ and $\mathrm{Pb}$ was observed in the liver. The concentration of $\mathrm{Cd}$ measured in the tissue correlated with the dose of $\mathrm{Cd}$ administered in that the $30 \mathrm{mg} / \mathrm{kg}$ b.w. Cd group had a Cd concentration in the liver that was twice as high as the $15 \mathrm{mg} / \mathrm{kg}$ b.w. dose. Measured levels of $\mathrm{Cd}$ in the liver were higher than in the blood or kidney, which was expected based on the route of administration and the duration of exposure used in the study. Additionally, the reason for this distribution is the high metallothionein (MT) synthesis in the liver [19,69]. Measured $\mathrm{Cd}$ concentration in the liver of the experimental group that received the mixture did not statistically differ from the individual dose regime, while $\mathrm{Pb}$ concentration was three times higher when compared to the single dose group. The obtained results are consistent with the measured levels of $\mathrm{Cd}$ and $\mathrm{Pb}$ in the blood after mixture administration ( $\mathrm{Cd}$ level was in line with control group, while $\mathrm{Pb}$ level was higher than a single dose). Similar results were obtained in a fifteen-day study on rats i.p. treated with $0.05 \mathrm{mg} \mathrm{Cd} / \mathrm{kg}$ b.w., $0.05 \mathrm{mg} \mathrm{Pb} / \mathrm{kg}$ b.w., and a combined treatment of $0.025 \mathrm{mg} \mathrm{Cd} / \mathrm{kg}$ b.w. + $0.025 \mathrm{mg} \mathrm{Pb} / \mathrm{kg}$ b.w. [39], where after mixture treatment levels of $\mathrm{Cd}$ and $\mathrm{Pb}$ in the liver were in line with single dose regimes. A possible reason for this observation might be toxicokinetic interactions between these two metals on the level of intestinal absorption, and thereby modified distribution in blood and tissues. Divalent cation transporter (DCT1), also known as DMT1, is one of the carriers and a possible participant in the interaction between toxic metals [70].

Although the exact mechanisms involved in $\mathrm{Cd}$ and $\mathrm{Pb}$ hepatotoxicity are not fully understood, their ability to alter oxidative status is significant. In the present study, we observed high AOPP levels after single metal treatments accompanied with a TAS fall, while MDA levels were unchanged. The strongest TAS decrease was observed in the $\mathrm{Pb}_{150}$ group. Contrary to these results, Djukic-Cosic et al. [71], after 6h of a single Cd dose (20 mg/kg b.w), applied orally, observed MDA increasing in mice liver, but decreasing after $48 \mathrm{~h}$, while Pillai et al. [39] reported an increase in TBARS levels after mixture and single $\mathrm{Cd}$, but not after single $\mathrm{Pb}$ treatment administered i.p. 15 days. Moreover, no significant changes were observed in MDA and AOPP liver levels after mixture administration. Our results are consistent with results obtained by Cobbina et al. [25] and Masso et al. [40], who did not find any MDA/TBARS increase in the liver of animals treated with a $\mathrm{Cd}$ and $\mathrm{Pb}$ mixture. Despite the fact that $\mathrm{Cd}$ and $\mathrm{Pb}$ given individually induced some oxidative damage in the liver, the lack of the effects of $\mathrm{Pb}$ and $\mathrm{Cd}$ co-exposure may be at least partly explained by the role of MT and smaller proportion of free metal able to lead to the oxidative stress disturbance [7]. Metallothioneins exist in four major forms and are present in different tissues. Synthesis of metallothionein stimulates both investigated toxic metals, although $\mathrm{Cd}$ in a more profound manner. By binding to toxic metals, MT protects tissues from being affected by metal ions. The Cd-MT complex is primarily formed in the liver and then slowly released into the circulation and reaches the kidneys $[7,19,56]$.

Changes in serum total protein values may indicate liver dysfunction as the liver is the main site of plasma proteins synthesis, primarily albumin [72]. Significantly lower values of total proteins and albumin were observed after mixture treatment, while single metals were not able to produce 
any change. Histopathological analysis did not reveal a serious disturbance of the liver structure that would lead to enzyme release. In line with this, we did not observe any elevation in serum AST and ALT activities. Contrary, both enzymes surprisingly showed a decreasing trend, but with significance only in the ALT activities of $\mathrm{Cd}_{30}$ and both Pb groups. While other authors recorded enzymes elevation [24-26], only a few record a decrease [73-75]. The observed decrease can be explained by the competition between toxic metals and divalent ions, such as $\mathrm{Mg}, \mathrm{Co}$, and $\mathrm{Mn}$; activators of the enzyme; and Zn, a constituent of the enzyme [72]. This is supported by the fact that we measured lower serum values of $\mathrm{Mg}$ in all treated groups, with the most pronounced reduction in groups treated with $\mathrm{Pb}$. Interaction between toxic metals and bioelements has been extensively studied by our research group and these studies confirmed many hypotheses; prolonged oral exposure to Cd significantly reduced $\mathrm{Zn}$ levels in blood and nine organs; $\mathrm{Cd}$ interferes with intestinal $\mathrm{Mg}$ absorption and affects its homeostasis; and $\mathrm{Cd}$ exposure results in negative effects on $\mathrm{Mg}, \mathrm{Zn}, \mathrm{Cu}$, and even iron tissue levels [12-14,41,42,76,77].

\subsection{Effects on Kidneys}

In line with $\mathrm{Cd}$ doses, the experimental group that received $30 \mathrm{mg} \mathrm{Cd} / \mathrm{kg}$ b.w. had a higher concentration in kidneys when compared to a lower Cd dose (73.5\%). After mixture exposure, measured levels of toxic metals in the kidneys were higher than after single metal treatments. Possible explanations might be the excretory function of the kidney and rich blood supply and secondly, the role of the MT [2,78]. The formed Cd-MT complex is slowly released from the liver into the circulation and reaches the kidneys. After filtration in the kidneys, $\mathrm{Cd}$ is reabsorbed in proximal tubules and deposited in the kidneys. Metallothionein dissolves by discharging the free metals form capable of producing damage $[7,19,56]$.

In the present work, higher $\mathrm{Cd}$ doses produced a more robust MDA elevation in kidneys compared to lower doses, yet these changes were not statistically significant compared to control values. On the other hand, $\mathrm{Pb}$ treatments increased kidneys MDA levels in comparison to the control, while the after mixture treatments increase was significant when compared to controls and the $\mathrm{Cd}_{15}$ group. Obtained results were similar to the results of other studies $[28,29,59,62,79,80]$. On the other hand, sub-chronic exposure to low $\mathrm{Cd}$ and $\mathrm{Pb}$ doses given as a single dose $(0.005 \mathrm{mg} \mathrm{Cd} / \mathrm{L}$ and $0.01 \mathrm{mg}$ $\mathrm{Pb} / \mathrm{L})$, as well as a mixture through free drinking water [25], did not produce any changes in MDA levels in mice kidneys. The different study design, the path of exposure, the dose, as well as the applied chemical form of metals are some of the possible explanations for the different results obtained between researchers. As we have already mentioned, many researches have shown that both metals lead to the formation of oxidative stress, whether applied individually or together, with different doses and exposure pathways, as recently reviewed by Matović et al. [7]. Obtained results for MDA levels suggest that the effect of combined exposure to $\mathrm{Cd}$ and $\mathrm{Pb}$ resulted in a more pronounced negative effect in kidneys versus the effects of individual metals, which is contrary to the results obtained in the liver. The changes we observed correlate with the changes in measured $\mathrm{Cd}$ and $\mathrm{Pb}$ concentrations in the kidneys after administration of the metal mixture. Once again, the role and presence of MT could be important for these findings [7]. Additivity or synergism is a well-known scenario in co-exposure to $\mathrm{Cd}$ and $\mathrm{Pb}$ in kidneys. However, the limitation of our study is the fact that our study design is inadequate for interaction evaluation according to the criteria given by Borgert et al. [81], so we can only claim additivity.

The renal profile parameter, urea, significantly decreased in all experimental dosage regimes, compared to untreated animals, while creatinine levels exhibited an increasing trend. Changes in urea and creatinine levels indicate that even after the administration of a single dose of toxic metals, the excretory function of the kidney might be impaired. Similar results of changes in the levels of urea and creatinine were observed in other studies [24-26,28]. Impaired excretory function is also supported by the fact that levels of some serum ions have been changed $(\mathrm{Ca}, \mathrm{Mg}, \mathrm{P}$, and $\mathrm{Cl})$, as well as levels of $\mathrm{Cu}$ and $\mathrm{Zn}$ in the blood and kidneys. The strongest decreasing in serum levels of $\mathrm{Ca}$ and $\mathrm{Mg}$ 
was observed after mixture treatment in comparison to the control group. On the other hand, a single Cd dose (30 mg/ $\mathrm{kg}$ b.w.) had a more prominent effect on the serum P level in blood, while a single $\mathrm{Pb}$ dose had a more pronounced effect on the $\mathrm{Cl}$ level. Additionally, a single dose of $\mathrm{Cd}(30 \mathrm{mg} / \mathrm{kg}$ b.w.) significantly decreased the $\mathrm{Zn}$ level in the blood, while all dose regimes decreased the kidney Zn levels.

\section{Conclusions}

Our results showed that acute exposure to $\mathrm{Cd}$ and/or $\mathrm{Pb}$ induced toxic effects in the blood, liver, and kidneys of adult Wistar rats. Oxidative stress is a major mechanism of toxicity for both metals and was implicated as a significant factor in our study, having observed a disturbed redox status in investigated tissues of treated rats. This study also showed a more profound toxicity of metal mixtures. Future studies should be focused on subacute or subchronic exposure to these metals and designed to enable interaction assessment.

Author Contributions: Conceptualization, A.B.D. and Z.B.; data curation, M.A., A.B.D., E.A., B.A., D.W., and Z.B.; formal analysis and investigation, M.A., E.A., M.S., J.K.-S., V.S.-K., M.J., and N.B.; statistics, M.A., E.A., and J.K.-S.; visualization, M.A.; Project administration, B.A. and V.S.-K.; Funding acquisition A.B.D., B.A., and D.W.; writing—original draft, M.A.; writing, reviewing and editing, A.B.D., D.W., B.A., and Z.B.; supervision Z.B.

Funding: The project was partly supported by the Ministry of Education, Science and Technological Development of Serbia (Project III 46009) and the Oklahoma State University Center for Health Science intramural funding (\#154333-7 to DRW).

Conflicts of Interest: The authors declare that no conflict of interest exists regarding this work. The funders had no role in the design of the study; in the collection, analyses, or interpretation of data; in the writing of the manuscript, and in the decision to publish the results.

\section{References}

1. Järup, L.; Åkesson, A. Current status of cadmium as an environmental health problem. Toxicol. Appl. Pharmacol. 2009, 238, 201-208. [CrossRef] [PubMed]

2. Casas, S.J.; Sordo, J. Lead Chemistry, Analytical Aspects, Environmental Impact and Health Effects; Elsevier: Amsterdam, The Netherlands, 2006; ISBN 9780444529459.

3. Satarug, S.; Garrett, S.H.; Sens, M.A.; Sens, D.A. Cadmium, environmental exposure, and health outcomes. Environ. Health Perspect. 2010, 118, 182-190. [CrossRef] [PubMed]

4. Tchounwou, P.B.; Yedjou, C.G.; Patlolla, A.K.; Sutton, D.J. Heavy metal toxicity and the environment. EXS 2012, 101, 133-164. [PubMed]

5. WHO Action Is Needed on Chemicals of Major Public Health Concern. Public Health Environmental 2010, pp. 1-4. Available online: https://www.who.int/ipcs/assessment/public_health/chemicals_phc/en/ (accessed on 26 September 2018).

6. ATSDR Substance Priority List I ATSDR. Available online: https://www.atsdr.cdc.gov/spl/ (accessed on 26 September 2018).

7. Matović, V.; Buha, A.; Dukić-Ćosić, D.; Bulat, Z. Insight into the oxidative stress induced by lead and/or cadmium in blood, liver and kidneys. Food Chem. Toxicol. 2015, 78, 130-140. [CrossRef] [PubMed]

8. Flora, S.J.S.; Agrawal, S. Arsenic, Cadmium, and Lead; Academic Press: Cambridge, MA, USA, 2017; ISBN 9780128042397.

9. Matović, V.; Buha, A.; Bulat, Z.; Dukić-Ćosić, D.; Đukić-Ćosić, D. Cadmium toxicity revisited: Focus on oxidative stress induction and interactions with zinc and magnesium. Arh. Hig. Rada Toksikol. 2011, 62, 65-76. [CrossRef] [PubMed]

10. Flora, G.; Gupta, D.; Tiwari, A. Toxicity of lead: A review with recent updates. Interdiscip. Toxicol. 2012, 5, 47-58. [CrossRef]

11. Nieboer, E.; Richardson, D.H.S. The replacement of the nondescript term "heavy metals" by a biologically and chemically significant classification of metal ions. Environ. Pollut. 1980, 1, 3-26. [CrossRef]

12. Djukić-Ćosić, D.; Ninković, M.; Maličević, Ž.; Plamenac-Bulat, Z.; Matović, V. Effect of supplemental magnesium on the kidney levels of cadmium, zinc, and copper of mice exposed to toxic levels of cadmium. Biol. Trace Elem. Res. 2006, 114, 281-292. [CrossRef] 
13. Bulat, Z.P.; Djukić-Ćosić, D.; Maličević, Ž.; Bulat, P.; Matović, V. Zinc or magnesium supplementation modulates Cd intoxication in blood, kidney, spleen, and bone of rabbits. Biol. Trace Elem. Res. 2008, 124, 110-117. [CrossRef]

14. Bulat, Z.; Dukić-Ćosić, D.; Antonijević, B.; Buha, A.; Bulat, P.; Pavlović, Z.; Matović, V. Can zinc supplementation ameliorate cadmium-induced alterations in the bioelement content in rabbits? Arh. Hig. Rada Toksikol. 2017, 68, 38-45. [CrossRef]

15. Rani, A.; Kumar, A.; Lal, A.; Pant, M. Cellular mechanisms of cadmium-induced toxicity: A review. Int. J. Environ. Health Res. 2014, 24, 378-399. [CrossRef] [PubMed]

16. Waisberg, M.; Joseph, P.; Hale, B.; Beyersmann, D. Molecular and cellular mechanisms of cadmium carcinogenesis. Toxicology 2003, 192, 95-117. [CrossRef]

17. Joseph, P. Mechanisms of cadmium carcinogenesis. Toxicol. Appl. Pharmacol. 2009, 238, 272-279. [CrossRef] [PubMed]

18. Ahmed, Y.F.; Eldebaky, H.A.A.; Mahmoud, K.G.M.; Nawito, M. Effects of lead exposure on DNA damage and apoptosis in reproductive and vital organs in female rabbits. Glob. Vet. 2012, 9, 401-408.

19. Świergosz-Kowalewska, R. Cadmium distribution and toxicity in tissues of small rodents. Microsc. Res. Tech. 2001, 55, 208-222. [CrossRef] [PubMed]

20. Timchalk, C.; Lin, Y.; Weitz, K.K.; Wu, H.; Gies, R.A.; Moore, D.A.; Yantasee, W. Disposition of lead (Pb) in saliva and blood of Sprague-Dawley rats following a single or repeated oral exposure to $\mathrm{Pb}$-acetate. Toxicology 2006, 222, 86-94. [CrossRef] [PubMed]

21. Abadin, H.; Ashizawa, A.; Stevens, Y.-W.; Llados, F.; Diamond, G.; Sage, G.; Citra, M.; Quinones, A.; Bosch, S.J.; Swarts, S.G. Toxicological Profile for Lead; The United States Public Health Service, Agency for Toxic Substances and Disease Registry: Atlanta, GA, USA, 2007; p. 582.

22. Agency for Toxic Substances and Disease Registry (ATSDR). Toxicological Profile for Cadmium; The United States Public Health Service, Agency for Toxic Substances and Disease Registry: Atlanta, GA, USA, 2012; pp. 1-487.

23. Horiguchi, H.; Oguma, E.; Kayama, F. Cadmium induces anemia through interdependent progress of hemolysis, body iron accumulation, and insufficient erythropoietin production in rats. Toxicol. Sci. 2011, 122, 198-210. [CrossRef]

24. Yuan, G.; Dai, S.; Yin, Z.; Lu, H.; Jia, R.; Xu, J.; Song, X.; Li, L.; Shu, Y.; Zhao, X. Toxicological assessment of combined lead and cadmium: Acute and sub-chronic toxicity study in rats. Food Chem. Toxicol. 2014, 65, 260-268. [CrossRef]

25. Cobbina, S.J.; Chen, Y.; Zhou, Z.; Wu, X.; Zhao, T.; Zhang, Z.; Feng, W.; Wang, W.; Li, Q.; Wu, X.; et al. Toxicity assessment due to sub-chronic exposure to individual and mixtures of four toxic heavy metals. J. Hazard. Mater. 2015, 294, 109-120. [CrossRef]

26. Yildirim, S.; Celikezen, F.C.; Oto, G.; Sengul, E.; Bulduk, M.; Tasdemir, M.; Ali Cinar, D. An investigation of protective effects of litium borate on blood and histopathological parameters in acute cadmium-induced rats. Biol. Trace Elem. Res. 2018, 182, 287-294. [CrossRef]

27. Shaban El-Neweshy, M.; Said El-Sayed, Y. Influence of vitamin C supplementation on lead-induced histopathological alterations in male rats. Exp. Toxicol. Pathol. 2011, 63, 221-227. [CrossRef] [PubMed]

28. El-Boshy, M.; Ashshi, A.; Gaith, M.; Qusty, N.; Bokhary, T.; AlTaweel, N.; Abdelhady, M. Studies on the protective effect of the artichoke (Cynara scolymus) leaf extract against cadmium toxicity-induced oxidative stress, hepatorenal damage, and immunosuppressive and hematological disorders in rats. Environ. Sci. Pollut. Res. 2017, 24, 12372-12383. [CrossRef] [PubMed]

29. Abdou, H.M.; Hassan, M.A. Protective role of omega-3 polyunsaturated fatty acid against lead acetate-induced toxicity in liver and kidney of female rats. BioMed Res. Int. 2014, 2014, 435857. [CrossRef] [PubMed]

30. Buha, A.; Matovic, V.; Antonijevic, B.; Bulat, Z.; Curcic, M.; Renieri, E.A.; Tsatsakis, A.M.; Schweitzer, A.; Wallace, D. Overview of cadmium thyroid disrupting effects and mechanisms. Int. J. Mol. Sci. 2018, 19, 1501. [CrossRef] [PubMed]

31. Buha, A.; Wallace, D.; Matovic, V.; Schweitzer, A.; Oluic, B.; Micic, D.; Djordjevic, V. Cadmium exposure as a putative risk factor for the development of pancreatic cancer: Three different lines of evidence. BioMed Res. Int. 2017, 2017, 1981837. [CrossRef] [PubMed] 
32. Mezynska, M.; Brzóska, M.M. Environmental exposure to cadmium-A risk for health of the general population in industrialized countries and preventive strategies. Environ. Sci. Pollut. Res. 2018, 25, 3211-3232. [CrossRef] [PubMed]

33. Carocci, A.; Catalano, A.; Lauria, G.; Sinicropi, M.S.; Genchi, G. Lead toxicity, antioxidant defense and environment. In Reviews of Environmental Contamination and Toxicology; Springer: Berlin, Germany, 2016; pp. 45-67.

34. ATSDR. Case Studies in Environmental Medicine (CSEM) Lead Toxicity; ATSDR: Atlanta, GA, USA, 2019.

35. Tang, L.; Chen, X.; Bao, Y.; Xu, W.; Lv, Y.; Wang, Z.; Wen, X. CT imaging biomarkers of bone damage induced by environmental level of cadmium exposure in male rats. Biol. Trace Elem. Res. 2016, 170, 146-151. [CrossRef] [PubMed]

36. International Agency for Research on Cancer (IARC). Agents Classified by the IARC Monographs, Volumes 1-121; IARC Monographs: Lyon, France, 2018; pp. 1-25.

37. Commission of the European Communities (CEC). A Europen Environment and Health Strategy. In Communication from the Commission to the Council, the Europen Parliament and the European Economics and Social Committee, Final; Commission of the European Communities: Brussels, Belgium, 2003.

38. Wang, G.; Fowler, B.A. Roles of biomarkers in evaluating interactions among mixtures of lead, cadmium and arsenic. Toxicol. Appl. Pharmacol. 2008, 233, 92-99. [CrossRef]

39. Pillai, A.; Gupta, S. Antioxidant enzyme activity and lipid peroxidation in liver of female rats co-exposed to lead and cadmium: Effects of vitamin $\mathrm{E}$ and $\mathrm{Mn}^{2+}$. Free Radic. Res. 2005, 39, 707-712. [CrossRef]

40. Massó, E.L.; Corredor, L.; Antonio, M.T. Oxidative damage in liver after perinatal intoxication with lead and/or cadmium. J. Trace Elem. Med. Biol. 2007, 21, 210-216. [CrossRef]

41. Matović, V.; Buha, A.; Bulat, Z.; Dukić-ćosić, D.; Miljković, M.; Ivanišević, J.; Kotur-Stevuljević, J. Route-dependent effects of cadmium/cadmium and magnesium acute treatment on parameters of oxidative stress in rat liver. Food Chem. Toxicol. 2012, 50, 552-557. [CrossRef] [PubMed]

42. Buha, A.; Bulat, Z.; Dukic-Cosic, D.; Matovic, V. Effects of oral and intraperitoneal magnesium treatment against cadmium-induced oxidative stress in plasma of rats. Arh. Hig. Rada Toksikol. 2012, 63, 247-254. [CrossRef] [PubMed]

43. Pawa, S.; Ali, S. Liver necrosis and fulminant hepatic failure in rats: Protection by oxyanionic form of tungsten. Biochim. Biophys. Acta Mol. Basis Dis. 2004, 1688, 210-222. [CrossRef] [PubMed]

44. Girotti, M.J.; Khan, N.; McLellan, B.A. Early measurement of systemic lipid peroxidation products in the plasma of major blunt trauma patients. J. Trauma 1991, 31, 32-35. [CrossRef] [PubMed]

45. Witko-Sarsat, V.; Friedlander, M.; Capeillère-Blandin, C.; Nguyen-Khoa, T.; Nguyen, A.T.; Zingraff, J.; Jungers, P.; Descamps-Latscha, B. Advanced oxidation protein products as a novel marker of oxidative stress in uremia. Kidney Int. 1996, 49, 1304-1313. [CrossRef] [PubMed]

46. Ellman, G.L. Tissue Sulfhydryl Groups. Arch. Biochem. Biophys. 1959, 82, 70-77. [CrossRef]

47. Alamdari, D.H.; Paletas, K.; Pegiou, T.; Sarigianni, M.; Befani, C.; Koliakos, G. A novel assay for the evaluation of the prooxidant-antioxidant balance, before and after antioxidant vitamin administration in type II diabetes patients. Clin. Biochem. 2007, 40, 248-254. [CrossRef]

48. Erel, O. A novel automated direct measurement method for total antioxidant capacity using a new generation, more stable ABTS radical cation. Clin. Biochem. 2004, 37, 277-285. [CrossRef]

49. Erel, O. A new automated colorimetric method for measuring total oxidant status. Clin. Biochem. 2005, 38, 1103-11111. [CrossRef]

50. Aycicek, A.; Erel, O. Total oxidant/antioxidant status in jaundiced newborns before and after phototherapy. J. Pediatr. 2007, 83, 319-322. [CrossRef]

51. Misra, H.P.; Fridovich, I. The role of superoxide anion in the autoxidation of epinephrine and a simple assay for superoxide dismutase. J. Biol. Chem. 1972, 247, 3170-3175. [PubMed]

52. Bradford, M.M. A rapid and sensitive method for the quantitation of microgram quantities of protein utilizing the principle of protein-dye binding. Anal. Biochem. 1976, 72, 248-254. [CrossRef]

53. Weichselbaum, T.E. An accurate and rapid method for the determination of proteins in small amounts of blood serum and plasma. Am. J. Clin. Pathol. 1946, 10, 40-49. [CrossRef] [PubMed]

54. Veglia, F.; Cighetti, G.; De Franceschi, M.; Zingaro, L.; Boccotti, L.; Tremoli, E.; Cavalca, V. Age- and gender-related oxidative status determined in healthy subjects by means of OXY-SCORE, a potential new comprehensive index. Biomarkers 2006, 11, 562-573. [CrossRef] [PubMed] 
55. Wu, B.; Liu, Z.; Xu, Y.; Li, D.; Li, M. Combined toxicity of cadmium and lead on the earthworm Eisenia fetida (Annelida, Oligochaeta). Ecotoxicol. Environ. Saf. 2012, 81, 122-126. [CrossRef] [PubMed]

56. Wu, X.; Cobbina, S.J.; Mao, G.; Xu, H.; Zhang, Z.; Yang, L. A review of toxicity and mechanisms of individual and mixtures of heavy metals in the environment. Environ. Sci. Pollut. Res. 2016, 1-16. [CrossRef] [PubMed]

57. Mladenović, J.; Ognjanović, B.; Dordević, N.; Matić, M.; Knežević, V.; Štajn, A.; Saičić, Z. Protective effects of oestradiol against cadmium-induced changes in blood parameters and oxidative damage in rats. Arh. Hig. Rada Toksikol. 2014, 65, 37-46. [CrossRef]

58. Karmakar, R.; Bhattacharya, R.; Chatterjee, M. Biochemical, haematological and histopathological study in relation to time-related cadmium-induced hepatotoxicity in mice. BioMetals 2000, 13, 231-239. [CrossRef]

59. El-Boshy, M.E.; Risha, E.F.; Abdelhamid, F.M.; Mubarak, M.S.; Hadda, T. Ben Protective effects of selenium against cadmium induced hematological disturbances, immunosuppressive, oxidative stress and hepatorenal damage in rats. J. Trace Elem. Med. Biol. 2015, 29, 104-110. [CrossRef]

60. Lafuente, A.; González-Carracedo, A.; Romero, A.; Esquifino, A.I. Effect of cadmium on lymphocyte subsets distribution in thymus and spleen. J. Physiol. Biochem. 2003, 59, 43-48. [CrossRef]

61. Omobowale, T.O.; Oyagbemi, A.A.; Akinrinde, A.S.; Saba, A.B.; Daramola, O.T.; Ogunpolu, B.S.; Olopade, J.O. Failure of recovery from lead induced hepatoxicity and disruption of erythrocyte antioxidant defence system in Wistar rats. Environ. Toxicol. Pharmacol. 2014, 37, 1202-1211. [CrossRef] [PubMed]

62. Sharma, V.; Sharma, A.; Kansal, L. The effect of oral administration of Allium sativum extracts on lead nitrate induced toxicity in male mice. Food Chem. Toxicol. 2010, 48, 928-936. [CrossRef] [PubMed]

63. Djokic, J.; Ninkov, M.; Mirkov, I.; Popov Aleksandrov, A.; Zolotarevski, L.; Kataranovski, D.; Kataranovski, M. Differential effects of cadmium administration on peripheral blood granulocytes in rats. Environ. Toxicol. Pharmacol. 2014, 37, 210-219. [CrossRef] [PubMed]

64. Kataranovski, M.; Janković, S.; Kataranovski, D.; Stoŝić, J.; Bogojević, D. Gender differences in acute cadmium-induced systemic inflammation in rats. BioMed Environ. Sci. 2009, 22, 1-7. [CrossRef]

65. Sharma, V.; Kansal, L.; Sharma, A.; Lodi, S.; Sharma, S. Ameliorating effect of coriandum sativum extracts on hematological and immunological variables in an animal model of lead intoxication. J. Pharm. Allied Health Serv. 2011, 1, 16-29.

66. Patra, R.C.; Rautray, A.K.; Swarup, D. Oxidative stress in lead and cadmium toxicity and its amelioration. Vet. Med. Int. 2011, 2011, 457327. [CrossRef] [PubMed]

67. Olisekodiaka, M.J.; Igbeneghu, C.A.; Onuegbu, A.J.; Oduru, R.; Lawal, A.O. Lipid, lipoproteins, total antioxidant status and organ changes in rats administered high doses of cadmium chloride. Med. Princ. Pract. 2012, 21, 156-159. [CrossRef] [PubMed]

68. Curcic, M.; Buha, A.; Stankovic, S.; Milovanovic, V.; Bulat, Z.; Đukić-Ćosić, D.; Antonijević, E.; Vučinić, S.; Matović, V.; Antonijevic, B. Interactions between cadmium and decabrominated diphenyl ether on blood cells count in rats-Multiple factorial regression analysis. Toxicology 2017, 376, 120-125. [CrossRef]

69. Nordberg, G.F. Historical perspectives on cadmium toxicology. Toxicol. Appl. Pharmacol. 2009, 238, $192-200$. [CrossRef]

70. Ballatori, N. Transport of toxic metals by molecular mimicry. Environ. Health Perspect. 2002, 110, 689-694. [CrossRef]

71. Djukić-Ćosić, D.; Ćurčić Jovanović, M.; Plamenac Bulat, Z.; Ninković, M.; Maličević, Ž.; Matović, V. Relation between lipid peroxidation and iron concentration in mouse liver after acute and subacute cadmium intoxication. J. Trace Elem. Med. Biol. 2008, 22, 66-72. [CrossRef]

72. Burtis, A.C.; Edwrd, R.; Bruns, E.D. Tietz: Fundamentals of Clinical Chemistry; Elsevier: Amsterdam, The Netherlands, 2001; ISBN 9780721638652.

73. Pande, M.; Mehta, A.; Pant, B.P.; Flora, S.J.S. Combined administration of a chelating agent and an antioxidant in the prevention and treatment of acute lead intoxication in rats. Environ. Toxicol. Pharmacol. 2001, 9, 173-184. [CrossRef]

74. Sivaprasad, R.; Nagaraj, M.; Varalakshmi, P. Combined efficacies of lipoic acid and 2,3-dimercaptosuccinic acid against lead-induced lipid peroxidation in rat liver. J. Nutr. Biochem. 2004, 15, 18-23. [CrossRef]

75. Zhu, H.; Jia, Y.; Cao, H.; Meng, F.; Liu, X. Biochemical and histopathological effects of subchronic oral exposure of rats to a mixture of five toxic elements. Food Chem. Toxicol. 2014, 71, 166-175. [CrossRef] [PubMed] 
76. Bulat, Z.; Đukić-Ćosić, D.; Antonijević, B.; Bulat, P.; Vujanović, D.; Buha, A.; Matović, V. Effect of magnesium supplementation on the distribution patterns of zinc, copper, and magnesium in rabbits exposed to prolonged cadmium intoxication. Sci. World J. 2012, 2012, 572514. [CrossRef] [PubMed]

77. Matović, V.; Bulat, Z.P.; Djukić-Ćosić, D.; Soldatović, D. Antagonism between cadmium and magnesium: A possible role of magnesium in therapy of cadmium intoxication. Magnes. Res. 2010, 23, 19-26. [PubMed]

78. Nordberg, G.F. Cadmium and health in the 21st Century-Historical remarks and trends for the future. BioMetals 2004, 17, 485-489. [CrossRef]

79. Yalin, S.; Comelekoglu, U.; Bagis, S.; Sahin, N.O.; Ogenler, O.; Hatungil, R. Acute effect of single-dose cadmium treatment on lipid peroxidation and antioxidant enzymes in ovariectomized rats. Ecotoxicol. Environ. Saf. 2006, 65, 140-144. [CrossRef]

80. Othman, A.I.; El Missiry, M.A. Role of selenium against lead toxicity in male rats. J. Biochem. Mol. Toxicol. 1998, 12, 345-349. [CrossRef]

81. Borgert, C.J.; Price, B.; Wells, C.S.; Simon, G.S. Evaluating chemical interaction studies for mixture risk assessment. Hum. Ecol. Risk Assess. Int. J. 2001, 7, 259-306. [CrossRef]

(C) 2019 by the authors. Licensee MDPI, Basel, Switzerland. This article is an open access article distributed under the terms and conditions of the Creative Commons Attribution (CC BY) license (http://creativecommons.org/licenses/by/4.0/). 